University of Rhode Island

DigitalCommons@URI

2015

\title{
Sea-level change and subsidence in the Delaware Estuary during the last $\sim 2200$ years
}

Daria Nikitina

Andrew C. Kemp

Simon E. Engelhart

University of Rhode Island, engelhart@uri.edu

Benjamin P. Horton

David F. Hill

See next page for additional authors

Follow this and additional works at: https://digitalcommons.uri.edu/geo_facpubs

This is a pre-publication author manuscript of the final, published article.

Creative Commons License

(c) (i) $\Theta \Theta$

This work is licensed under a Creative Commons Attribution-Noncommercial-No Derivative Works 4.0 License.

\section{Citation/Publisher Attribution}

Nikitina, D., Kemp, A. C., Engelhart, S. E., Horton, B. P., Hill, D. F., \& Kopp, R. E. (2015). Sea-level change and subsidence in the Delaware Estuary during the last $\sim 2200$ years. Estuarine, Coastal and Shelf Science, 165, 506-519. doi: 10.1016/j.ecss.2015.08.012

Available at: https://doi.org/10.1016/j.ecss.2015.08.012

This Article is brought to you for free and open access by the Geosciences at DigitalCommons@URI. It has been accepted for inclusion in Geosciences Faculty Publications by an authorized administrator of DigitalCommons@URI.For more information, please contact digitalcommons-group@uri.edu. 


\section{Authors}

Daria Nikitina, Andrew C. Kemp, Simon E. Engelhart, Benjamin P. Horton, David F. Hill, and Robert E. Kopp 


\section{SEA-LEVEL CHANGE AND SUBSIDENCE IN THE DELAWARE ESTUARY DURING THE LAST 2200 YEARS}

Daria Nikitina $^{1}{ }^{*}$, Andrew C. Kemp ${ }^{2}$, Simon E. Engelhart ${ }^{3}$, Benjamin P. Horton ${ }^{4,5,6}$, David F. Hill ${ }^{7}$ and Robert E. Kopp ${ }^{5,8}$

1. Department of Geology and Astronomy, West Chester University, West Chester, PA, USA.

2. Department of Earth and Ocean Sciences, Tufts University, Medford, MA 02155, USA.

3. Department of Geosciences, University of Rhode Island, Kingston, RI 02881, USA.

4. Department of Marine and Coastal Sciences, Rutgers University, New Brunswick, NJ 08901, USA.

5. Institute of Earth, Ocean, \& Atmospheric Sciences, Rutgers University, New Brunswick, NJ 08901, USA.

6. Division of Earth Sciences and Asian School of the Environment, Nanyang Technological University, 639798, Singapore.

7. School of Civil and Construction Engineering, Oregon State University, Corvallis, OR, 97331, USA.

8. Department of Earth \& Planetary Sciences and Rutgers Energy Institute, Rutgers University, Piscataway, NJ 08854, USA.

- Corresponding author: dnikitina@wcupa.edu; 610-436-3103

Keywords: glacial-isostatic adjustment,salt marsh; tidal range; peat; New Jersey; the U.S. Atlantic coast 


\section{INTRODUCTION}

Proxy reconstructions are important for understanding the driving mechanisms of past relative sea-level (RSL) trends and for constraining predictions of future sea-level change (e.g., Dutton et al., 2015). On the U.S. Atlantic coast the principal cause of prolonged, regional RSL change during the Common Era (last 2000 years) was glacio-isostatic adjustment (GIA), driven by collapse of the Laurentide Ice Sheet's proglacial forebulge (e.g., Peltier, 1996). This process causes a change in the geoid height and the local radius of the solid Earth relative to Earth's center of mass (Farrell and Clark, 1976). Despite disintegration of the Laurentide ice sheet by 7000 years before present (BP; e.g., Carlson et al., 2008), GIA on the U.S. Atlantic coast continues to the present day (e.g., Engelhart et al., 2009), because of the slow response time ( 4000 years) of the solid Earth to redistribution of mass during deglaciation (Peltier, 1998). RSL also includes contributions from other processes causing vertical land motion (Kopp et al., 2015) such as sediment compaction (e.g., Miller et al., 2013), dynamic topography (e.g., Rowley et al., 2013), and tectonics (e.g., van de Plassche et al., 2014). For convenience, we use the term "land-level change" to describe the net effect of GIA and these other sources of vertical land motion. Accurate estimates of land-level change are important for generating regional sea-level projections (e.g., Kopp et al., In Press), isolating the climate-driven components of RSL trends measured by tide gauges and satellite altimetry (e.g., Church and White, 2011; Nerem et al., 2010), and testing Earth-ice models (e.g., Roy and Peltier, 2015).

In the absence of long-term instrumental measurements, rates of land-land change can be estimated from RSL reconstructions spanning the last 1000 to 4000 years (Engelhart et al., 2009; Shennan and Horton, 2002; Engelhart et al., 2015). This approach assumes that the non-land-level change component of reconstructed RSL over this period was zero or minimal (Bassett et al., 2005; Lambeck et al., 2014; Milne et al., 2005; Peltier, 2002) A standardized database of RSL reconstructions from the U.S. Atlantic Coast demonstrated that spatially-variable rates of land-level change (and RSL rise) during the last 4000 years reflect distance from the former center of the Laurentide Ice Sheet (Engelhart and Horton, 2012; Engelhart et al., 2009). After grouping RSL reconstructions by location, Engelhart et al. (2009) estimated the rate of subsidence for 16 regions from Maine to South Carolina. Maximum subsidence $(1.7 \pm 0.2$ $\mathrm{mm} / \mathrm{yr}$ ) occurred in the upper Delaware Bay. However, the vertical and temporal uncertainties on individual RSL reconstructions from the Delaware Bay were relatively large and were not formally accounted for when estimating rates of RSL change based on linear regression of reconstruction mid points. Furthermore, such estimates did not include the influence of tidal-range change, a process shown to be significant in the Delaware Bay during the Holocene (Belknap, 1975; Belknap and Kraft, 1977; Hall et al., 2013; Leorri et al., 2011). A similar pattern of subsidence was identified by isolating the 


\section{STUDY REGION}

Sea Breeze, NJ is located on the northeastern shore of the Delaware Bay (Figure 1). The modern salt marsh at Sea Breeze displays the characteristic regional pattern of floral zonation. Low salt-marsh areas between mean tidal level (MTL) and mean high water (MHW) on the shore of Delaware Bay and along tidal channels are vegetated by Spartina alterniflora (tall form). The high marsh is the largest zone by area and lies between MHW and mean higher high water (MHHW). It is vegetated by Spartina patens, Distichlis spicata, and the short form of Spartina alterniflora. The border between salt marsh and freshwater upland at elevations from MHHW to highest astronomical tide (HAT) is a brackish zone vegetated by Schoenoplectus spp. and Phragmites australis. Great diurnal tidal range (mean lower low water, MLLW to MHHW) measured at the NOAA tide gauge nearest to Sea Breeze (Ship John Shoal; 
Figure 1) is $1.79 \mathrm{~m}$. Marine influence reached the region at $\sim 6000$ years BP when tidal wetlands began to establish around the Delaware Bay (e.g., Leorri et al., 2006; Nikitina et al., 2003). Continuous RSL rise since then resulted in the Sea Breeze salt marsh being underlain by 2-4 m of salt-marsh and intertidal sediments (Nikitina et al., 2014).

Modern salt-marsh foraminifera in southern New Jersey form at least seven distinctive assemblages (Kemp et al., 2012; Kemp et al., 2013c). The dominant species of foraminifera in low-marsh floral zones are Miliammina fusca and Ammobaculites spp. High-marsh floral zones are populated by assemblages of foraminifera in which Trochammina inflata, Arenoparrella mexicana, and Tiphotrocha comprimata are the most abundant species. At brackish sites with strong fluvial influence, Ammoastuta inepta is the characteristic high-marsh species. The transition between salt-marsh and fresh-water ecosystems is dominated by Haplophragmoides manilaensis.

\section{MATERIALS AND METHODS}

\subsection{Core SELECTION, RECOVERY, AND ELEVATION}

A detailed lithotratigraphic investigation of the Sea Breeze site was completed from 59 exploratory gouge cores. The site is unsuitable for continuous reconstructions of Common Era RSL change because the stratigraphy beneath the modern salt marsh reveals peats that are intercalated by inorganic units that likely resulted in sediment compaction. Furthermore, the site was subjected to repeated erosion during hurricanes or large storms resulting in a fragmentary and incomplete sedimentary record (Nikitina et al., 2014). Therefore, we selected eight cores that contained basal peats to generate eight new sea-level index points between $3.21 \mathrm{~m}$ and $0.59 \mathrm{~m}$ below North American Vertical Datum 1988 (NAVD88). In each case, a $0.5 \mathrm{~m}$ depth interval was sampled to capture the transition from incompressible, sandy, pre-Holocene substrate to overlying organic sediment. Samples were collected using a Russian-type hand auger to minimize compaction and/or contamination of sediment during recovery. Cores were transferred to labeled PVC pipes, sealed in plastic wrap, and held in refrigerated storage until processing.

Core top elevations were referenced to NAVD88 by leveling to nearby benchmarks with a total station. Elevations were converted to tidal elevations using VDatum (v2.3.5) and the New Jersey Coastal Embayment regional dataset. At Sea Breeze, NAVD88 is $0.06 \mathrm{~m}$ above MTL.

\subsection{RADIOCARBON DATING}


The cores recovered from Sea Breeze were processed to isolate plant macrofossils in growth position from the sediment matrix. Identification of the macrofossils was made by comparison with modern equivalents and published descriptions (Niering et al., 1977). To minimize the contribution of sediment compaction to RSL reconstruction, samples for radiocarbon dating were selected from as close to the basal contact as possible. Samples were first cleaned using distilled water under a binocular microscope to remove contaminating material including adhered organic sediment and in-growing rootlets and then oven dried at $<45{ }^{\circ} \mathrm{C}$. The dry samples where weighed and submitted to the National Ocean Sciences Accelerator Mass Spectrometry (NOSAMS) radiocarbon dating laboratory. All samples underwent acidbase-acid pretreatment to remove carbonate and humic acids. A portion of $\mathrm{CO}_{2}$ collected during sample combustion provided $\delta^{13} \mathrm{C}$ values and was used to correct the sample for natural fractionation during its formation. Individual radiocarbon dates were calibrated using the IntCal13 (Reimer et al., 2013) dataset and are presented with $2 \sigma$ calibrated uncertainties where zero is $1950 \mathrm{CE}$ (Table 1 ).

\subsection{FORAMINIFERA AND THE INDICATIVE MEANING}

Foraminifera were enumerated from 1-cm thick slices of core material. These samples were sieved under running water to disaggregate the sediment and retain the fraction in the $63-500 \mu \mathrm{m}$ size range. A minimum of 100 individuals were counted wet from each sample under a binocular microscope, which is sufficient to accurately describe low-diversity assemblages that are typical of salt-marsh sediment (e.g. Horton and Edwards, 2006). Species identifications were confirmed by comparison with type slides of individuals collected from modern salt marshes in the study area (Kemp et al., 2012; Kemp et al., 2013c).

We estimated the indicative meaning of dated samples at Sea Breeze (Table 2) and in the regional Delaware Bay database (Table 3) based on sediment character, preserved plant macrofossils, and foraminifera. We classified samples as having been deposited in either a high salt-marsh, low salt-marsh or undifferentiated salt-marsh environment. Following the definitions of Engelhart and Horton (2012), we applied an indicative range of MTL to MHW and MHW to HAT for low- and high-marsh samples, respectively. For undifferentiated salt-marsh samples an indicative range of MTL to HAT was applied.

\subsection{PALEOTIDAL MODELING}

Tidal data for Delaware Bay were predicted using the approach from Hall et al. (2013). To briefly summarize their methods, a high-resolution finite-element mesh, with horizontal spacing of 80-175 m, 
was created for the Delaware Bay. This high-resolution mesh was combined with the coarser Western North Atlantic grid (Mukai et al., 2002) to create an overall model grid with regional scope, but high resolution locally in the study area. The baseline grid, created with present-bay bathymetric data sets, was combined with RSL predictions from the ICE-6G VM5b model (Engelhart et al., 2011b) in order to produce paleobathymetries from 0 to 7000 years BP at 1000 year intervals. Leorri et al. (2011) and Hall et al. (2013) both noted that the bathymetric change from the late Holocene to present day exhibited considerable spatial variability across the Delaware Bay. Offshore open boundary forcing was obtained from the TPXO 7.2 model (Egbert et al., 1994). This model provides the amplitudes and phases of the eight principal tidal constituents. For the paleo-tidal simulations, the present-day open boundary forcing was used. This was justified since previous work by Hill et al. (2011) showed that tides in the northern Atlantic did not change appreciably from 0 to 7000 years BP.

The ADCIRC model (Luettich and Westerink, 1991) was used to simulate the tides in the domain. Wetting and drying was enabled in order to properly model the intertidal zone and finite amplitude effects, and nonlinear bottom friction were included in order to capture the generation of overtides in shallow water. The tidal model did not include models of sediment infilling of either the estuaries or coastal lowlands or freshwater discharge from the catchments (Shennan et al., 2000). For each time slice of interest, a 90-day simulation was carried out. Harmonic analysis of the results allowed for the determination of the tidal amplitudes and phases in the interior of the domain. These results were converted to tidal datums, such as MHHW and mean low water (MLW), using the method of Mofjeld et al. (2004). HAT at each model node was computed as the sum of the tidal amplitudes at that node. The paleotidal model was used to modify reference water levels and indicative ranges for all index points (Sea Breeze and the Delaware Bay database). Following Horton et al. (2013), data at locations other than the model grid points (e.g., a field sampling site) were obtained through interpolation. We compared the model predictions of tidal datums with the three tide gauges in Delaware Bay. The root mean squared error of the misfit between predicted and observed datums is $\pm 0.14 \mathrm{~m}$ (i.e. the tidal model error to reconstruct current tides, after Shennan et al., 2000).

\subsection{RECONSTRUCTING RELATIVE SEA LEVEL}

RSL was reconstructed by subtracting the estimated indicative meaning from measured sample altitude (Shennan and Horton, 2002):

$\mathrm{RSL}_{i}=\mathrm{A}_{i}-\mathrm{RWL}_{i}$ 
where $\mathrm{A}_{i}$ is the altitude of sample $i$ established by measuring depth in a core with a known surface elevation. $\mathrm{RWL}_{i}$ is the reference water level assigned to sample $i . \mathrm{A}_{i}$ and $\mathrm{RWL}_{i}$ are expressed relative to the same tidal datum (e.g., MTL) so that for a modern (surface) sample the two terms are equal and RSL is $0 \mathrm{~m}$. The vertical position of RSL for each index point is expressed in relation to this value where negative values indicate RSL below present.

The total vertical error $\left(\mathrm{TE}_{i}\right)$ for each sample was calculated from the expression (Shennan and Horton, 2002):

$\mathrm{TE}_{i}=\left(\mathrm{IR}^{2}+\mathrm{e}^{2}{ }_{1}+\mathrm{e}_{\mathrm{n}}^{2}\right)^{1 / 2}$

where IR is the indicative range and $\mathrm{e}_{1} \ldots \mathrm{e}_{\mathrm{n}}$ are the individual sources of sampling error for sample $i$. For the Sea Breeze index points this includes: (1) benchmark error of $\pm 0.10 \mathrm{~m}$; (2) leveling error of $\pm 0.05 \mathrm{~m}$; (3) sample thickness error of $\pm 0.01 \mathrm{~m}$; (4) core angle error of $\pm 1 \%$ of depth; (5) tidal modeling error of \pm $0.14 \mathrm{~m}$; and (6) Russian core sampling error of $\pm 0.01 \mathrm{~m}$.

\subsection{STATISTICAL FRAMEWORK TO ASSESS SPATIAL VARIABILITY OF RSL}

We assessed the spatial variability of RSL in Delaware Bay using a spatio-temporal empirical hierarchical model (Cressie and Wikle, 2011) applied to the Sea Breeze reconstruction and database of sea-level index points $(n=65)$. Spatio-temporal hierarchical models have been previously used to analyze paleo-sea level data (e.g., Kopp et al., In Press), as well as spatio-temporal fields ranging from surface winds (e.g., Wikle et al., 2001) to species populations (e.g., Wikle, 2003) to paleo-temperature (e.g., Tingey and Huybers, 2010). By explicitly modeling the spatio-temporal covariance structure, they enable the testing of hypotheses about site-to-site similarities and differences, which cannot be done self-consistently by comparing analyses of individual sites (see discussion in Kopp, 2013).

RSL at each space point was modeled as the sum of basin-wide sea-level change and a more localized linear trend:

$f(\mathbf{x}, t)=l(\mathbf{x})\left(t-t_{0}\right)+s(t)$

where $t_{0}$ is a reference time period (here, $1800 \mathrm{CE}$ ). The spatial covariance of the linear trend and the temporal covariance of the basinal sea-level signal were both modeled with mean-zero Gaussian process priors (Rasmussen and Williams, 2005):

$l(x) \sim G P\left\{0, \sigma_{l}^{2} \gamma\left(x, x^{\prime} ; \lambda\right)\right\}$ 


$$
s(t) \sim G P\left\{0, \sigma_{m}^{2} \rho\left(t, t^{\prime} ; \tau\right)\right\}
$$

where $\gamma\left(x, x^{\prime} ; \lambda\right)$ is an exponential covariance function and $\rho\left(t, t^{\prime} ; \tau\right)$ a Matérn covariance function with smoothness parameter $3 / 2$. The observed sea-level indicators were modeled as the sum of the true sea level and a white noise term with variance based on the total error estimated using equation (4). For samples that were not basal peats, an additional error equal to an optimized hyperparameter $\kappa$ times sample depth was added to account for compaction-related uncertainty. Geochronological uncertainty was incorporated through the noisy-input Gaussian process approximation of McHutchon and Rasmussen (2011):

$y_{i}=f\left(\mathbf{x}_{\mathbf{i}}, \hat{t}_{i}+\delta_{i}\right)+\varepsilon_{i} \approx f\left(\mathbf{x}_{\mathbf{i}}, \hat{t}_{i}\right)+f^{\prime}\left(\mathbf{x}_{\mathbf{i}}, \hat{t}_{i}\right) \delta_{i}+\varepsilon_{i}$

Here, $\hat{t}_{i}$ is the mean estimate of the calibrated age of indicator $i, \delta_{\mathrm{i}}$ is the error in this estimate (approximated as normally distributed), and $\varepsilon_{i}$ is the vertical error. We employ simulated annealing followed by local optimization to find the hyperparameters that maximize the likelihood of the model, conditional upon all the index points in the data set: $\sigma_{1}=2.5 \mathrm{~mm} / \mathrm{y}, \lambda=4.5^{\circ}, \sigma_{\mathrm{m}}=620 \mathrm{~mm}, \tau=760 \mathrm{y}$, and $\kappa=0.013$.

\section{RESULTS}

\subsection{LITHO, BIO AND CHRONOSTRATIGRAPHY OF SEA BREEZE SEA-LEVEL INDEX POINTS}

The Sea Breeze salt marsh is underlain by fluvial and tidal sediments consisting of five lithologic units (Figure 2). Gray, fine-to-medium compacted fluvial sand was deposited in the area prior to the Holocene transgression. The lowest stratigraphic unit above the pre-Holocene surface is an amorphous, black, humic, sandy mud that we interpreted as a paleosol. A gray-brown to dark-brown fibrous peat with fragments of Schoenoplectus sp., Spartina patens, and Distichlis spicata macrofossils overlies the paleosol. The macrofossils present within the peat indicate that it accumulated in brackish and high salt-marsh environments. A gray mud described at different stratigraphic levels above high-marsh peat represents tidal-flat deposits. A gray-brown, muddy peat with abundant Spartina alterniflora fragments was likely deposited in a low-marsh environment.

Core SB30 had a surface elevation of $1.04 \mathrm{~m} \mathrm{MTL} \mathrm{(Figure} \mathrm{3A).} \mathrm{A} \mathrm{fragment} \mathrm{of} \mathrm{a} \mathrm{Schoenoplectus} \mathrm{sp.} \mathrm{plant}$ recovered at $3.40 \mathrm{~m}$ depth in amorphous black sandy organic-rich sediment yielded an age of $1760 \pm 25$ radiocarbon years BP (Table 1). The calibrated age range for the date was 1736 to 1569 years BP. Dominant foraminifera between $3.36 \mathrm{~m}$ and $3.44 \mathrm{~m}$ were Arenoparrella mexicana with Jadammina 
macrescens and Tiphotrocha comprimata. Foraminifera and plant macrofossils indicated that the sample formed in a high salt-marsh floral environment and was assigned a reference water level of the midpoint between MHW and HAT and an indicative range of MHW to HAT. The resulting sea-level index point was produced directly at the contact with the incompressible sand substrate.

Core SB32 had a surface elevation of 1.07 m MTL (Figure 3B). An in-situ Distichlis spicata rhizome was recovered at $4.21 \mathrm{~m}$ depth in a unit of dark, compacted, brown peat with woody fragments and the remains of Phragmites australis plants. It yielded an age of $2210 \pm 30$ radiocarbon years BP (Table 1) that calibrated to 2325-2149 years BP. Dominant foraminifera in the interval between $4.18 \mathrm{~m}$ and $4.21 \mathrm{~m}$ were Jadammina macrescens and Tiphotrocha comprimata. Samples at $4.22 \mathrm{~m}$ and $4.23 \mathrm{~m}$ included a small number of Jadammina macrescens. Foraminifera and plant macrofossils indicated that the sample formed in a high salt-marsh floral environment and was assigned a reference water level of the midpoint between MHW and HAT and an indicative range of MHW to HAT. The resulting sea-level index point was $0.01 \mathrm{~m}$ above the basal contact.

Core SB76 had a surface elevation of $0.86 \mathrm{~m}$ MTL (Figure 3C). An in-situ vertical stem and attached rhizome of Schoenoplectus sp. was recovered at 1.57-1.63 m depth in high salt-marsh peat and yielded an age of $960 \pm 25$ radiocarbon years BP (Table 1). The calibrated age range for the date was 929-795 years BP. The assemblage of foraminifera at the dated level included Jadammina macrescens and Tiphotrocha comprimata. Three deeper samples at $1.57 \mathrm{~m}, 1.58 \mathrm{~m}$ and $1.59 \mathrm{~m}$ included a small number of Tiphotrocha comprimata. Foraminifera and plant macrofossils indicated that the sample formed in a high salt-marsh floral environment and was assigned a reference water level of the midpoint between MHW and HAT and an indicative range of MHW to HAT. The resulting sea-level index point was at the basal contact as the rhizome was growing into the sandy substrate.

Core SB81 had a surface elevation of $0.74 \mathrm{~m}$ MTL (Figure 3D). A fragment of a Phragmites australis stem recovered at $3.20 \mathrm{~m}$ depth in amorphous black sediment yielded an age of $1840 \pm 30$ radiocarbon years BP (Table 1). The associated calibrated age range was 1865-1708 years BP. Dominant foraminifera between $3.16 \mathrm{~m}$ and $3.22 \mathrm{~m}$ were Arenoparrella mexicana with Ammoastuta inepta. A sample at $3.24 \mathrm{~m}$ included just three individual foraminifera (two Trochammina inflata and one Jadammina macrescens). Foraminifera and plant macrofossils indicated that the sample formed in a high salt-marsh floral environment and was assigned a reference water level of the midpoint between MHW and HAT and an indicative range of MHW to HAT. The resulting sea-level index point was $0.1 \mathrm{~m}$ above the basal contact. Core SB83 had a surface elevation of 0.84 m MTL (Figure 3E). An in-situ Spartina patens rhizome recovered at $2.77 \mathrm{~m}$ depth in high salt-marsh peat sediment yielded an age of $1740 \pm 30$ radiocarbon years 

foraminifera between $2.73 \mathrm{~m}$ and $2.77 \mathrm{~m}$ were Ammoastuta inepta, Arenoparrella mexicana and Tiphotrocha comprimata. A sample at $2.78 \mathrm{~m}$ was dominated by Jadammina macrescens with foraminifera absent from deeper samples. Foraminifera and plant macrofossils indicated that the sample formed in a high salt-marsh floral environment and was assigned a reference water level of the midpoint between MHW and HAT and an indicative range of MHW to HAT. The resulting sea-level index point was $0.13 \mathrm{~m}$ above the basal contact.

Core SB84 had a surface elevation of $0.72 \mathrm{~m} \mathrm{MTL} \mathrm{(Figure} \mathrm{3F).} \mathrm{An} \mathrm{in-situ} \mathrm{macrofossil} \mathrm{of} \mathrm{Distichlis}$ spicata rhizome recovered at $2.22 \mathrm{~m}$ depth in amorphous black sediment yielded a radiocarbon age of $1260 \pm 25$ years BP (Table 1). The calibrated age range for the sample was 1280-1091 years BP. The transition to high salt-marsh peat sediment was documented in the core at the depth of $2.21 \mathrm{~m}$. Dominant foraminifera between $2.21 \mathrm{~m}$ and $2.24 \mathrm{~m}$ were Jadammina macrescens and Tiphotrocha comprimata. Foraminifera and plant macrofossils indicated that the sample formed in a high salt-marsh floral environment and was assigned a reference water level of the midpoint between MHW and HAT and an indicative range of MHW to HAT. The resulting sea-level index point was $0.15 \mathrm{~m}$ above the contact with sand.

Core SB98 had a surface elevation of $0.78 \mathrm{~m}$ (Figure 3G). An in-situ macrofossil of Spartina patens recovered at $2.03 \mathrm{~m}$ depth in amorphous black sediment yielded an age of $1010 \pm 25$ radiocarbon years BP (Table 1). The calibrated age of the sample was 969-905 years BP. The stratigraphy changed to mud at a depth of $2.00 \mathrm{~m}$. A sample at $1.99 \mathrm{~m}$ was dominated by Tiphotrocha comprimata, while samples between $2.01 \mathrm{~m}$ and $2.07 \mathrm{~m}$ were characterized by high abundances of Jadammina macrescens. Foraminifera and plant macrofossils indicated that the sample formed in a high salt-marsh floral environment and was assigned a reference water level of the midpoint between MHW and HAT and an indicative range of MHW to HAT. The resulting sea-level index point was $0.07 \mathrm{~m}$ above the basal contact.

Core SB1 10 had a surface elevation of $0.83 \mathrm{~m}$ MTL (Figure 3H). A rhizome of Spartina patens rooted in an underlying palesol sedimentary unit at $1.35 \mathrm{~m}$ depth yielded an age of $830 \pm 25$ radiocarbon years BP (Table 1). Its calibrated age was 784-690 years BP. A sample at $1.31 \mathrm{~m}$ was dominated by Jadammina macrescens (93\%), but samples at $1.32 \mathrm{~m}, 1.33 \mathrm{~m}$ and $1.35 \mathrm{~m}$ had few foraminifera. Foraminifera and plant macrofossils indicated that the sample formed in a high salt-marsh floral environment and was assigned a reference water level of the midpoint between MHW and HAT and an indicative range of MHW to HAT. The resulting sea-level index point was $0.15 \mathrm{~m}$ above the basal contact. 


\subsection{PALEOTIDES IN DELAWARE BAY}

While regional tidal model results showed minimal changes to deep-ocean Great Diurnal Range (GT) during the Common Era (Hill et al., 2011), results in the Delaware Bay showed significant spatial and temporal variability. The variability within the Delaware Bay can be seen in Figure 4, which shows contours of GT at 2000 and 1000 years BP, along with present day. Present day GT is largest ( 1.8 m) in the Delaware River and upper reaches of the Delaware Bay (Figure 4A). GT at the river mouth in lower reaches of the bay is $\sim 1.4 \mathrm{~m}$ and decreases further with distance beyond the bay and onto the continental shelf. At 2000 years BP, GT in the upper Delaware Bay was $<1 \mathrm{~m}$, while in the lower reaches of the bay GT was similar to present, indicating a sharp spatial gradient in the temporal rate of change in GT (Figure 4C). The paleogeographic evolution of Delaware Bay from a narrow river at $\sim 4000$ years BP to the familiar funnel shaped bay of today (Hall et al., 2013) is the most likely explanation for the large changes in upper bay GT, compared to the lower bay. Changes in tidal range do not affect all types of sea-level index points (high marsh, low marsh, undifferentiated marsh) evenly. The greatest changes in reference water level and indicative ranges are for high-marsh deposits that are located in the upper Bay. The reference water level of the four index points from Sea Breeze dated between 1500 and 2200 years BP decreased from $0.98 \mathrm{~m}$ to $0.60 \mathrm{~m}$. The indicative range was reduced from $0.20 \mathrm{~m}$ to $0.15 \mathrm{~m}$.

\section{DISCUSSION}

\subsection{RSL CHANGE AT SEA BREEZE AND ASSESSMENT OF ERRORS}

The eight new sea-level index points from Sea Breeze reconstruct RSL change on the New Jersey coast of the Delaware Bay. After correction for tidal-range changes, the new reconstruction shows that RSL rose from approximately $-3.8 \mathrm{~m}$ at 2200 years BP to $-1.4 \mathrm{~m}$ at 700 years BP (Figure 5A). The average rate of RSL rise from 2200 to 150 years BP, estimated using the spatio-temporal empirical hierarchical model, was $1.12 \pm 0.22 \mathrm{~mm} / \mathrm{yr}(2 \sigma$ uncertainty).

Comparison of the Sea Breeze RSL record with published Delaware Bay sea-level index points shows that application of modern techniques results in improved precision compared to older reconstructions (Figure 5B) that were generated by studies published as early as 1972 (index point \#29, Table 2). It is important to note that there is no systematic defference in the RSL reconstructed by older and more recent studies, indicating that all index points in the regional database accurately reconstruct former RSL 

Hijma et al., 2015). RSL reconstructions require that sample altitude (part of term $\mathrm{A}_{i}$ in equation 1) is known. In some of the studies from which sea level index points were compiled and standardized by Engelhart and Horton (2012), the core top elevation was either not measured or not explicitly reported and could only be estimated from a description of the surface coring environment such as "salt marsh" or "high salt marsh". In part this was because the original studies were not necessarily seeking to reconstruct RSL. Since these environments span a range of elevations, some sample altitudes in the database have an uncertainty of up to $\pm 0.9 \mathrm{~m}$ (e.g., index point \#28). Improved surveying instruments resulted in smaller sampling uncertainties, this is particularly true where real time kinematic satellite navigations and digital total stations enabled core tops to be leveled accurately and precisely to a network of survey markers since these are rarely located on or close to salt marshes. The indicative range of the samples was not reduced by using foraminifera at Sea Breeze, because we used the foraminiferal assemblages to support the clear vertical division of plants into high and low salt-marsh floral zones that reflect the varied tolerances of plant species to tidal flooding (Gehrels, 1994; Redfield, 1972; van de Plassche, 1991). This methodology allows direct comparisons between sea-level reconstructions that were produced from different sea-level indicators.

Advancements in radiocarbon dating significantly improved the vertical and temporal precision of RSL reconstructions derived from salt-marsh sediment. Many of the radiocarbon dates reported in older studies were produced by the so-called conventional or radiometric method (measurement of $\beta$ emissions by liquid scintillation or gas proportional counting). In contrast, newer reconstructions (including the one from Sea Breeze) used Accelerator Mass Spectrometry (AMS) to radiocarbon date individual plant remains by measuring the relative number of ${ }^{14} \mathrm{C}$ and ${ }^{13} \mathrm{C}$ atoms. AMS dating does not necessarily yield a smaller analytical uncertainty than the conventional method (Cook and van der Plicht, 2007). However, the shift to AMS dating has two important implications for the uncertainties of RSL reconstructions. Firstly, sampling error is reduced, because it allows small and well-defined samples such as individual plant macrofossils to be accurately dated. In contrast, conventional radiocarbon dating of salt-marsh material usually required a much larger sample and undifferentiated bulk sediment was commonly used. Short-lived plant macrofossils contain carbon that accumulated during just a few years. Although bulk salt-marsh sediment commonly consists of in situ material, it can also include transported macrofossils and unidentifiable carbon in the surrounding sediment matrix from varied sources and of varied ages (Dicken et al., 2004; Grimm et al., 2009; Hu, 2010; Kemp et al., 2013b; Törnqvist et al., 1990; 2015; van de Plassche, 1982). This difference is reflected in a small sample uncertainty for individual plant macrofossils and a large sample uncertainty for bulk sediment, irrespective of the analytical method used 


\subsection{RATE OF RSL AND SUBSIDENCE IN DELAWARE BAY}

During the last 2200 years, eustatic sea-level change was zero (e.g., Bassett et al., 2005; Milne et al., 2005; Peltier, 2002) or minimal (0.1-0.2 mm/yr; Lambeck, 2002; Lambeck et al., 2014), making GIA the predominant control on RSL change in eastern North America (e.g., Davis and Mitrovica, 1996). For this reason, we assume that linear Common Era RSL trends approximate rates of land-level change, which we defined as the net effect of GIA, tectonics, and sediment compaction.

Engelhart et al. (2009) suggested that the rate of RSL rise during the late Holocene in the upper Delaware Bay $(1.7 \pm 0.2 \mathrm{~mm} / \mathrm{yr})$ was the fastest rate along the U.S. Atlantic coast and greater than in the lower 

for the northern area and 1.1 to $1.2 \pm 0.2 \mathrm{~mm} / \mathrm{yr}$ in the southern part. These analyses (like many others, e.g., Gehrels and Woodworth, 2012) were based on linear regression of the mid point of all sea-level index points from a single region. This approach does not account for the vertical or temporal error associated with any RSL reconstruction. We addressed this limitation by applying the spatio-temporal empirical hierarchical model to the expanded Delaware Bay database (Engelhart and Horton, 2012 with the new Sea Breeze reconstructions) to account for the vertical and temporal uncertainties of each index point.

The use of a temporal Gaussian process prior for the sea-level signal allows for non-linear variations in this term, while the spatial model for land-level change allows information to be shared between adjacent sites. Importantly, the spatial model also allows for fully consistent comparisons of differences in rates of RSL between sites that allow for the presence of both common signals and site-specific changes. Such models have been previously applied to a variety of historic (Kopp, 2013) and late Holocene (Kemp et al., 2014, van de Plasshe et al., 2014; Engelhart et al., 2015, Kopp et al., In Press) sea-level data sets. By fitting the spatio-temporal field as a whole and thus accounting for the correlation of sea-level change between sites, they allow statistically robust estimation of multi-site averages and differences.

Prior to tidal correction, the average rate of RSL change at sites in the upper bay was $1.45 \pm 0.34 \mathrm{~mm} / \mathrm{yr}$, and the average rate in the lower bay was $1.11 \pm 0.30 \mathrm{~mm} / \mathrm{yr}$. The probability that sea-level rose faster in the upper bay was $97 \%$. Following correction for tidal-range change rates of RSL change within the Delaware Bay during the last 2200 years do not show a significant difference between the upper (1.26 \pm $0.33 \mathrm{~mm} / \mathrm{yr})$ and lower Bay $(1.15 \pm 0.29 \mathrm{~mm} / \mathrm{yr})$ and the probability of faster sea-level rise in the upper bay falls to $73 \%$ (Figure 6; Table 3). The paleotidal model indicates that corrections of RSL reconstructions for tidal-range change are greatest (up to $0.4 \mathrm{~m}$ ) in the upper bay. This convergence is consistent with predictions from Earth-ice models (Engelhart et al., 2011a; Roy and Peltier, 2015) that do not show different rates of Common Era RSL rise between the upper and lower Bay and likely explains why agreement was observed between models and data only in the upper Bay (Engelhart et al., 2011) A similar study by Shennan and Horton (2002) and Horton and Shennan (2009) in eastern England found that the changes in tidal range at the open coast are relatively small, but within the large estuaries of the Humber and the Wash modeled tidal ranges were significantly less in the late Holocene. The modeled changes for both the Humber inner and outer estuary offered an explanation for the apparent differences between the RSL reconstructions produced from these location. Shennan and Horton (2002) concluded that the rate of Common Era land subsidence within estuaries is prone to being overestimated unless tidalrange changes are quantified. 
The slightly lower mean estimate of the rates in the lower bay result from the influence of two neighboring sites: Cape Henlopen ( $1.00 \pm 0.35 \mathrm{~mm} / \mathrm{yr})$ and Great Marsh/Broadkill Beach $(0.81 \pm 0.42$ $\mathrm{mm} / \mathrm{yr}$ ). Excluding these two sites, the average rate in the lower bay after tidal correction is increased to $1.30 \pm 0.36 \mathrm{~mm} / \mathrm{yr}$ and is indistinguishable from the rate in the upper bay (probability of a higher rate in the upper bay than the lower bay $=41 \%$ ). The Cape Henlopen spit currently curves from the south to the north-west around a breakwater built early in the $19^{\text {th }}$ century (Kraft et al., 1978). The spit previously had a cuspate foreland that recurved over the past 300 to 2,000 years (Kraft et al., 1978). Such intricate paleography is not included in the current paleotidal model and, furthermore, such depositional environments have a complex relation with sea level (Belknap and Kraft, 1977; Long et al., 2014).

The highest mean estimates of the rates of RSL rise in Delaware Bay occur at Jake's Landing, NJ (1.49 \pm $0.87 \mathrm{~mm} / \mathrm{yr}$ ). The high rates are supported by Varekamp and Thomas (1998), who estimated a rate of RSL rise of $6.9 \mathrm{~mm} / \mathrm{yr}$ since the $1650 \mathrm{CE}$, using ${ }^{210} \mathrm{~Pb}$ and AMS radiocarbon dating salt-marsh sediment at the site. This historic rates is much higher than a comparable study from Cape May, NJ (Kemp et al., 2013a). This region is susceptible to compaction due to the thick muds created by the Dennis Creek drainage system that underlie the salt-marsh peat (Meyerson, 1972). The compaction of salt-marsh stratigraphies cause post-depositional lowering of salt-marsh samples used to reconstruct sea level, because of compaction creates an estimation of former sea level that is too low and a rate of rise that is too great (Belknap and Kraft, 1977; Bloom, 1964; Brain et al., 2012; Horton and Shennan, 2009; Kaye and Barghoorn, 1964). We propose that the anomalously high rates of RSL rise at Jake's Landing are the result of rapid and localized sediment compaction.

Excluding Cape Henlopen, Great Marsh, and Jake's Landing, the tidal-range-corrected rate of RSL rise in Delaware Bay over the last $2200 \mathrm{yr}(1.25 \pm 0.27 \mathrm{~mm} / \mathrm{yr})$ is indistinguishable from the $1.3 \pm 0.1 \mathrm{~mm} / \mathrm{yr}$ estimated for the New Jersey Atlantic coast (Horton et al., 2013), which was also corrected for tidal range changes (Figure 5C). This rate is also comparable to rates estimate for the Delaware Atlantic coast (Horse Island, $1.39 \pm 0.48 \mathrm{~mm} / \mathrm{yr}$; and Rehoboth Bay, $1.29 \pm 0.78 \mathrm{~mm} / \mathrm{yr}$ ). This similarity among the Atlantic coast of Delaware, New Jersey and the inner and outer parts of the Delaware estuary support inferences from Earth-ice models, tide-gauge records (e.g., Kopp, 2013), and global positioning systems (e.g., Sella et al., 2007; Snay et al., 2007) that maximum rates of land-level changes along the U.S. Atlantic coast occur in the mid-Atlantic region.

\section{CONCLUSIONS}


We have produced a new RSL record covering the last $~ 2200$ years from a series of eight basal salt-marsh peat samples. We estimated the elevation at which these samples formed (the indicative meaning) by using plant macrofossils supported by foraminiferal assemblages. Our new sea-level index points have significantly improved vertical and age precision compared to previously available data due primarily to high-resolution leveling methods and the use of AMS radiocarbon dating of in-situ plant macrofossils. We utilized a previously developed high-resolution tidal model for the Delaware Bay (Hall et al., 2013) to estimate the effects of changes in tidal range during the late Holocene and to correct our RSL record. Not considering the effects of tidal range would result in an over-estimation of the rate of rise at Sea Breeze of $0.2 \mathrm{~mm} / \mathrm{yr}$. We estimated a rate of RSL rise from 2200 to 150 years BP at Sea Breeze of $1.12 \pm 0.22$ $\mathrm{mm} / \mathrm{yr}$ using a spatio-temporal empirical hierarchical model.

Utilizing the paleotidal correction removes the difference previously observed between RSL change in the upper and lower Delaware Bay (e.g., Engelhart et al., 2009; Leorri et al., 2013). We estimate the rates of RSL are $1.26 \pm 0.33 \mathrm{~mm} / \mathrm{yr}$ and $1.30 \pm 0.36 \mathrm{~mm} / \mathrm{yr}$ for the upper and lower Bay, respectively. The rates of rise now estimated for Delaware Bay $(1.25 \pm 0.27 \mathrm{~mm} / \mathrm{yr})$ using the tidal corrections are similar to the $\sim 1.3 \mathrm{~mm} / \mathrm{yr}$ observed in sites less prone to the influence of tidal range in New Jersey, Maryland, and Virginia, confirming earlier research that the maximal ongoing forebulge collapse is focused on the midAtlantic. Our improvement in the precision of index points and the application of a spatio-temporal empirical hierarchical model will enable further advances in the understanding of the regional (eustatic, glacio-isostatic and hydro-isostatic) and the local (coastal morphology, sediment supply, tidal regime and terrestrial and fluvial input) processes that control RSL.

\section{ACKNOWLEDGMENTS}

We thank Chris Vane, West Chester University and Earthwatch students for valuable field assistance. Funding for this study was provided by EPA grant 96284800, NICRR grant DE-FC02-06ER64298, National Science Foundation awards EAR 1052848, 1402017, OCE 1458903 and ARC 1203415, NOAA grants NA11OAR4310101 and NA10OAR4170075, and New Jersey Sea Grant Consortium project 64100012, and USDA National Institute of Food and Agriculture, Hatch funding and the Rhode Island Agricultural Experiment Station. This paper is a contribution to PALSEA 2. 


\section{TABLES}

TABLE 1: RADIOCARBON DATES

\begin{tabular}{|c|c|c|c|c|c|c|c|}
\hline Core (Depth) & Latitude & Longitude & $\begin{array}{l}\text { Altitude (m } \\
\text { MTL) }\end{array}$ & $\begin{array}{l}\text { Lab } \\
\text { Identifier }\end{array}$ & ${ }^{14} \mathrm{C}$ Age $\pm 1 \sigma$ & $\begin{array}{l}\delta^{13} \mathrm{C}(\%) \\
\text { PDB })\end{array}$ & Dated Material \\
\hline SB30 (340cm) & 39.31634 & -75.3150 & -2.36 & OS-84497 & $1760 \pm 25$ & -24.63 & Schoenoplectus sp. fragment \\
\hline SB32 $(421 \mathrm{~cm})$ & 39.3147 & -75.315 & -3.16 & OS-88743 & $2210 \pm 30$ & -14.72 & Distichlis spicata rhizome \\
\hline SB76 (163m) & 39.32461 & -75.317 & -0.77 & OS-88662 & $960 \pm 25$ & -22.73 & Schoenoplectus sp. stem and rhizome \\
\hline SB81 (320cm) & 39.3217 & -75.319 & -2.46 & OS-88661 & $1840 \pm 30$ & -25.94 & Fragment of Phragmites australis stem \\
\hline SB83 (277cm) & 39.3217 & -75.318 & -1.93 & OS-80666 & $1740 \pm 30$ & -13.83 & Spartina patens rhizome \\
\hline SB84 (222cm) & 39.3220 & -75.317 & -1.5 & OS-88663 & $1260 \pm 25$ & -13.60 & Distichlis spicata rhizome \\
\hline SB98 $(203 \mathrm{~cm})$ & 39.3229 & -75.3159 & -1.25 & OS-80667 & $1010 \pm 25$ & -12.76 & Spartina patens \\
\hline $\begin{array}{l}\text { SB110 } \\
(135 \mathrm{~cm})\end{array}$ & 39.3238 & -75.315 & -0.52 & OS-80668 & $830 \pm 25$ & -12.55 & Spartina patens rhizome \\
\hline
\end{tabular}

All age determinations were made at the National Ocean Sciences Accelerator Mass Spectrometry (NOSAMS) facility (OS lab identifiers).

Reported ages follow rounding conventions and are in expressed in radiocarbon years before present. Samples underwent acid-base-acid pretreatment. $\delta^{13} \mathrm{C}$ (relative to Pee Dee Belemnite, $\mathrm{PDB}$ ) was measured in an aliquot of $\mathrm{CO}_{2}$ gas collected during sample combustion and was used to correct ${ }^{14} \mathrm{C}$ measurements. The reported $\delta^{13} \mathrm{C}$ values are for the dated macrofossil and do not represent bulk sediment. 
TABLE 2: SUMMARY OF SEA-LEVEL INDEX POINTS FROM THE DELAWARE BAY DATABASE AFTER CORRECTION FOR TIDAL RANGE CHANGE

\begin{tabular}{|c|c|c|c|c|c|c|c|c|c|c|c|c|}
\hline $\begin{array}{l}\text { Index } \\
\text { point }\end{array}$ & $\begin{array}{l}\text { Site } \\
\text { Name }\end{array}$ & $\begin{array}{l}\text { Latitude } \\
\left({ }^{\circ} \mathrm{N},\right. \\
\text { decimal } \\
\text { degrees) }\end{array}$ & $\begin{array}{l}\text { Longitude } \\
\left({ }^{\circ} \mathbf{E},\right. \\
\text { decimal } \\
\text { degrees) }\end{array}$ & $\begin{array}{l}\text { Lab } \\
\text { Identifier }\end{array}$ & $\begin{array}{l}{ }^{14} \mathrm{C} \text { Age } \\
\pm 1 \sigma\end{array}$ & $\begin{array}{l}\text { Calibrated } \\
\text { age range } \\
(2 \sigma \text { years } \\
\text { before } \\
\text { present, } \\
1950 \mathrm{CE})\end{array}$ & $\begin{array}{l}\text { Tidal } \\
\text { range } \\
\text { correcti } \\
\text { on }(\mathbf{m})\end{array}$ & $\begin{array}{l}\text { Altitude } \\
\text { (m MTL) }\end{array}$ & $\begin{array}{l}\text { Reference } \\
\text { water } \\
\text { level (m } \\
\text { MTL) }\end{array}$ & RSL (m) & Type & Citation \\
\hline 1 & Bowers & 39.0486 & -75.3883 & P-1687 & $1952 \pm 45$ & $2002-1745$ & -0.11 & -1.77 & 0.37 & $-2.14 \pm 0.96$ & $\begin{array}{l}\text { Intercala } \\
\text { ted }\end{array}$ & $\begin{array}{l}\text { Belknap } \\
(1975)\end{array}$ \\
\hline 2 & Bowers & 39.0519 & -75.3903 & P-1686 & $1950 \pm 55$ & $2036-1736$ & -0.11 & -4.06 & 0.37 & $-4.43 \pm 0.95$ & Basal & $\begin{array}{l}\text { Belknap } \\
\text { (1975) }\end{array}$ \\
\hline 3 & $\begin{array}{l}\text { Broadkill } \\
\text { Beach }\end{array}$ & 38.8019 & -75.2044 & $\mathrm{I}-4353$ & $1990 \pm 100$ & $2300-1706$ & -0.02 & -3.55 & 0.77 & $-4.32 \pm 0.82$ & Basal & $\begin{array}{l}\text { Belknap } \\
\text { (1975) }\end{array}$ \\
\hline 4 & $\begin{array}{l}\text { Cape } \\
\text { Henlopen }\end{array}$ & 38.7639 & -75.0972 & TEM-158 & $280 \pm 60$ & $496-0$ & 0.00 & -0.58 & 0.40 & $-0.98 \pm 0.95$ & Basal & $\begin{array}{l}\text { DGS } \\
\text { (unpublished) }\end{array}$ \\
\hline 5 & $\begin{array}{l}\text { Cape } \\
\text { Henlopen }\end{array}$ & 38.7653 & -75.0986 & TEM-164 & $690 \pm 100$ & $892-513$ & -0.02 & -0.97 & 0.37 & $-1.34 \pm 0.95$ & Basal & $\begin{array}{l}\text { DGS } \\
\text { (unpublished) }\end{array}$ \\
\hline 6 & $\begin{array}{l}\text { Cape } \\
\text { Henlopen }\end{array}$ & 38.7642 & -75.0975 & TEM-163 & $750 \pm 70$ & $896-555$ & -0.02 & -1.37 & 0.37 & $-1.74 \pm 0.95$ & Basal & $\begin{array}{l}\text { DGS } \\
\text { (unpublished) }\end{array}$ \\
\hline 7 & $\begin{array}{l}\text { Cape } \\
\text { Henlopen }\end{array}$ & 38.7681 & -75.1056 & TEM-165 & $760 \pm 70$ & $900-558$ & -0.02 & -1.43 & 0.38 & $-1.81 \pm 0.95$ & Basal & $\begin{array}{l}\text { DGS } \\
\text { (unpublished) }\end{array}$ \\
\hline 8 & $\begin{array}{l}\text { Cape } \\
\text { Henlopen }\end{array}$ & 38.7600 & -75.1000 & I-8119 & $920 \pm 90$ & $980-677$ & -0.02 & -1.54 & 0.37 & $-1.91 \pm 0.95$ & Basal & $\begin{array}{l}\text { Belknap } \\
\text { (1975) }\end{array}$ \\
\hline 9 & $\begin{array}{l}\text { Cape } \\
\text { Henlopen }\end{array}$ & 38.7642 & -75.0975 & TEM-162 & $930 \pm 90$ & $1046-680$ & -0.02 & -0.79 & 0.37 & $-1.16 \pm 0.95$ & Basal & $\begin{array}{l}\text { DGS } \\
\text { (unpublished) }\end{array}$ \\
\hline
\end{tabular}




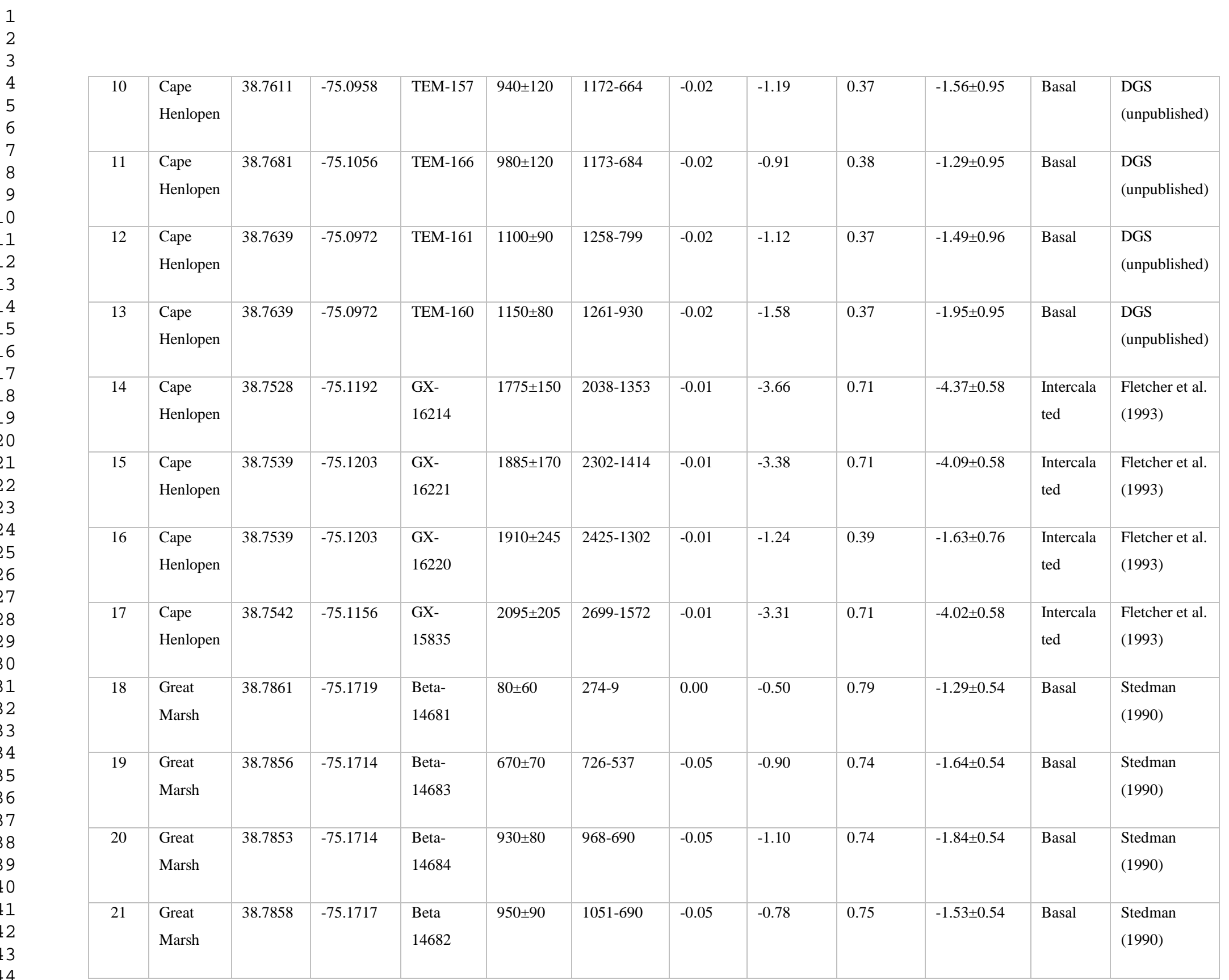




\begin{tabular}{|c|c|c|c|c|c|c|c|c|c|c|c|c|}
\hline 22 & $\begin{array}{l}\text { Great } \\
\text { Marsh }\end{array}$ & 38.7853 & -75.1711 & $\begin{array}{l}\text { Beta- } \\
14685\end{array}$ & $1150 \pm 80$ & $1261-930$ & -0.05 & -1.00 & 0.74 & $-1.74 \pm 0.54$ & Basal & $\begin{array}{l}\text { Stedman } \\
\text { (1990) }\end{array}$ \\
\hline 23 & $\begin{array}{l}\text { Great } \\
\text { Marsh }\end{array}$ & 38.7850 & -75.1708 & $\begin{array}{l}\text { Beta- } \\
14686\end{array}$ & $1370 \pm 60$ & $1385-1180$ & -0.05 & -1.20 & 0.74 & $-1.94 \pm 0.54$ & Basal & $\begin{array}{l}\text { Stedman } \\
(1990)\end{array}$ \\
\hline 24 & $\begin{array}{l}\text { Great } \\
\text { Marsh }\end{array}$ & 38.7847 & -75.1706 & $\begin{array}{l}\text { Beta- } \\
14687\end{array}$ & $1650 \pm 70$ & $1711-1389$ & -0.01 & -1.45 & 0.40 & $-1.85 \pm 0.75$ & Basal & $\begin{array}{l}\text { Stedman } \\
\text { (1990) }\end{array}$ \\
\hline 25 & $\begin{array}{l}\text { Great } \\
\text { Marsh }\end{array}$ & 38.7781 & -75.1736 & $\mathrm{I}-4625$ & $2330 \pm 100$ & $2714-2135$ & -0.01 & -4.71 & 0.40 & $-5.11 \pm 0.97$ & Basal & $\begin{array}{l}\text { Belknap } \\
(1975)\end{array}$ \\
\hline 26 & $\begin{array}{l}\text { Horse } \\
\text { Island } \\
\text { Marsh }\end{array}$ & 38.6717 & -75.1342 & $\begin{array}{l}\text { Beta- } \\
118808\end{array}$ & $170 \pm 80$ & $426-0$ & 0.00 & -0.73 & 0.70 & $-1.43 \pm 0.49$ & Basal & $\begin{array}{l}\text { Nikitina et al. } \\
(2000)\end{array}$ \\
\hline 27 & $\begin{array}{l}\text { Horse } \\
\text { Island } \\
\text { Marsh }\end{array}$ & 38.6717 & -75.1342 & $\begin{array}{l}\text { Beta- } \\
118807\end{array}$ & $960 \pm 50$ & $960-764$ & -0.03 & -1.45 & 0.67 & $-2.12 \pm 0.49$ & Basal & $\begin{array}{l}\text { Nikitina et al. } \\
(2000)\end{array}$ \\
\hline 28 & $\begin{array}{l}\text { Horse } \\
\text { Island } \\
\text { Marsh }\end{array}$ & 38.6700 & -75.1300 & $\begin{array}{l}\text { Beta- } \\
118811\end{array}$ & $1810 \pm 60$ & $1876-1572$ & -0.01 & -3.29 & 0.38 & $-3.67 \pm 1.07$ & $\begin{array}{l}\text { Intercala } \\
\text { ted }\end{array}$ & $\begin{array}{l}\text { DGS } \\
\text { (unpublished) }\end{array}$ \\
\hline 29 & $\begin{array}{l}\text { Jakes } \\
\text { Landing }\end{array}$ & 39.1700 & -74.8600 & Teledyne & $1335 \pm 95$ & $1413-999$ & -0.09 & -2.35 & 0.78 & $-3.13 \pm 0.94$ & $\begin{array}{l}\text { Intercala } \\
\text { ted }\end{array}$ & $\begin{array}{l}\text { Meyerson } \\
(1972)\end{array}$ \\
\hline 30 & $\begin{array}{l}\text { Leipsic } \\
\text { River }\end{array}$ & 39.2497 & -75.4695 & $\begin{array}{l}\text { Beta- } \\
118804\end{array}$ & $80 \pm 60$ & $274-9$ & 0.00 & -0.56 & 0.90 & $-1.46 \pm 0.49$ & $\begin{array}{l}\text { Intercala } \\
\text { ted }\end{array}$ & $\begin{array}{l}\text { Nikitina } \\
\text { (2003) }\end{array}$ \\
\hline 31 & $\begin{array}{l}\text { Leipsic } \\
\text { River }\end{array}$ & 39.2486 & -75.4583 & $\begin{array}{l}\text { Beta- } \\
118801\end{array}$ & $300 \pm 60$ & $502-0$ & 0.00 & -0.61 & 0.90 & $-1.51 \pm 0.49$ & $\begin{array}{l}\text { Intercala } \\
\text { ted }\end{array}$ & $\begin{array}{l}\text { Nikitina } \\
\text { (2003) }\end{array}$ \\
\hline 32 & Leipsic & 39.2525 & -75.4597 & Beta- & $970 \pm 80$ & $1055-709$ & -0.16 & -1.22 & 0.74 & $-1.96 \pm 0.48$ & Basal & Nikitina et al. \\
\hline
\end{tabular}




\begin{tabular}{|c|c|c|c|c|c|c|c|c|c|c|c|c|}
\hline & River & & & 118799 & & & & & & & & (2000) \\
\hline 33 & $\begin{array}{l}\text { Leipsic } \\
\text { River }\end{array}$ & 39.2464 & -75.4106 & $\begin{array}{l}\text { Beta- } \\
117238\end{array}$ & $1130 \pm 100$ & $1281-803$ & -0.16 & -1.46 & 0.75 & $-2.21 \pm 0.48$ & $\begin{array}{l}\text { Intercala } \\
\text { ted }\end{array}$ & $\begin{array}{l}\text { Nikitina } \\
\text { (2003) }\end{array}$ \\
\hline 34 & $\begin{array}{l}\text { Leipsic } \\
\text { River }\end{array}$ & 39.2511 & -75.4686 & $\begin{array}{l}\text { GrN- } \\
18995\end{array}$ & $1160 \pm 50$ & $1229-961$ & -0.16 & -2.52 & 0.74 & $-3.26 \pm 0.48$ & Basal & $\begin{array}{l}\text { Nikitina et al. } \\
\text { (2000) }\end{array}$ \\
\hline 35 & $\begin{array}{l}\text { Leipsic } \\
\text { River }\end{array}$ & 39.2489 & -75.4569 & $\begin{array}{l}\text { Beta- } \\
118800\end{array}$ & $1770 \pm 60$ & $1857-1552$ & -0.35 & -2.84 & 0.55 & $-3.39 \pm 0.47$ & Basal & $\begin{array}{l}\text { Nikitina et al. } \\
\text { (2000) }\end{array}$ \\
\hline 36 & $\begin{array}{l}\text { Leipsic } \\
\text { River }\end{array}$ & 39.2506 & -75.4689 & $\begin{array}{l}\text { GrN- } \\
18994\end{array}$ & $2030 \pm 80$ & $2301-1818$ & -0.34 & -2.85 & 0.55 & $-3.40 \pm 0.47$ & Basal & $\begin{array}{l}\text { Nikitina et al. } \\
\text { (2000) }\end{array}$ \\
\hline 37 & $\begin{array}{l}\text { Leipsic } \\
\text { River }\end{array}$ & 39.2494 & -75.4689 & $\begin{array}{l}\text { Beta- } \\
118803\end{array}$ & $2070 \pm 80$ & $2306-1870$ & -0.34 & -2.50 & 0.55 & $-3.05 \pm 0.47$ & Basal & $\begin{array}{l}\text { Nikitina et al. } \\
(2000)\end{array}$ \\
\hline 38 & $\begin{array}{l}\text { Marsh } \\
\text { Island }\end{array}$ & 38.6700 & -75.1300 & I-8118 & $690 \pm 85$ & $780-530$ & -0.02 & -0.90 & 0.37 & $-1.27 \pm 0.94$ & Basal & $\begin{array}{l}\text { Belknap } \\
(1975)\end{array}$ \\
\hline 39 & $\begin{array}{l}\text { Rehoboth } \\
\text { Bay }\end{array}$ & 38.6694 & -75.0683 & R-4101_a & $250 \pm 140$ & $501-0$ & 0.00 & -0.77 & 0.38 & $-1.15 \pm 0.96$ & $\begin{array}{l}\text { Intercala } \\
\text { ted }\end{array}$ & $\begin{array}{l}\text { Belknap } \\
\text { (1975) }\end{array}$ \\
\hline 40 & $\begin{array}{l}\text { Rehoboth } \\
\text { Bay }\end{array}$ & 38.6694 & -75.0700 & R-4100_a & $350 \pm 130$ & $629-0$ & 0.00 & -0.38 & 0.68 & $-1.06 \pm 0.83$ & $\begin{array}{l}\text { Intercala } \\
\text { ted }\end{array}$ & $\begin{array}{l}\text { Belknap } \\
(1975)\end{array}$ \\
\hline 41 & $\begin{array}{l}\text { Sea } \\
\text { Breeze }\end{array}$ & 39.3162 & -75.3153 & $\begin{array}{l}\text { OS- } \\
84498\end{array}$ & $165 \pm 25$ & $285-0$ & 0.00 & -0.25 & 0.93 & $-1.18 \pm 0.28$ & $\begin{array}{l}\text { Intercala } \\
\text { ted }\end{array}$ & $\begin{array}{l}\text { Nikitina et al. } \\
\text { (2014) }\end{array}$ \\
\hline 42 & $\begin{array}{l}\text { Sea } \\
\text { Breeze }\end{array}$ & 39.3191 & -75.3179 & $\begin{array}{l}\text { OS- } \\
80662\end{array}$ & $365 \pm 25$ & $499-318$ & 0.00 & -0.83 & 0.93 & $-1.76 \pm 0.28$ & $\begin{array}{l}\text { Intercala } \\
\text { ted }\end{array}$ & $\begin{array}{l}\text { Nikitina et al. } \\
\text { (2014) }\end{array}$ \\
\hline 43 & $\begin{array}{l}\text { Sea } \\
\text { Breeze }\end{array}$ & 39.3204 & -75.3177 & $\begin{array}{l}\text { OS- } \\
84495\end{array}$ & $425 \pm 25$ & $521-340$ & 0.00 & -1.08 & 0.30 & $-1.38 \pm 0.46$ & $\begin{array}{l}\text { Intercala } \\
\text { ted }\end{array}$ & $\begin{array}{l}\text { Nikitina et al. } \\
\text { (2014) }\end{array}$ \\
\hline
\end{tabular}




\begin{tabular}{|c|c|c|c|c|c|c|c|c|c|c|c|c|}
\hline 44 & $\begin{array}{l}\text { Sea } \\
\text { Breeze }\end{array}$ & 39.3191 & -75.3179 & $\begin{array}{l}\text { OS- } \\
80692\end{array}$ & $535 \pm 30$ & $632-512$ & -0.07 & -1.03 & 0.23 & $-1.26 \pm 0.40$ & $\begin{array}{l}\text { Intercala } \\
\text { ted }\end{array}$ & $\begin{array}{l}\text { Nikitina et al. } \\
\text { (2014) }\end{array}$ \\
\hline 45 & $\begin{array}{l}\text { Sea } \\
\text { Breeze }\end{array}$ & 39.3146 & -75.3158 & $\begin{array}{l}\text { Beta- } \\
240760\end{array}$ & $810 \pm 40$ & $789-674$ & -0.06 & -1.30 & 0.23 & $-1.53 \pm 0.40$ & $\begin{array}{l}\text { Intercala } \\
\text { ted }\end{array}$ & $\begin{array}{l}\text { Nikitina et al. } \\
\text { (2014) }\end{array}$ \\
\hline 46 & $\begin{array}{l}\text { Sea } \\
\text { Breeze }\end{array}$ & 39.3191 & -75.3180 & $\begin{array}{l}\text { Beta- } \\
252034\end{array}$ & $810 \pm 40$ & $789-674$ & -0.06 & -1.68 & 0.23 & $-1.91 \pm 0.40$ & $\begin{array}{l}\text { Intercala } \\
\text { ted }\end{array}$ & $\begin{array}{l}\text { Nikitina et al. } \\
\text { (2014) }\end{array}$ \\
\hline 47 & $\begin{array}{l}\text { Sea } \\
\text { Breeze }\end{array}$ & 39.3238 & -75.3153 & $\begin{array}{l}\text { OS- } \\
80668\end{array}$ & $830 \pm 25$ & $784-692$ & -0.16 & -0.65 & 0.77 & $-1.42 \pm 0.26$ & Basal & This paper \\
\hline 48 & $\begin{array}{l}\text { Sea } \\
\text { Breeze }\end{array}$ & 39.3191 & -75.3179 & $\begin{array}{l}\text { OS- } \\
88662\end{array}$ & $960 \pm 25$ & $929-796$ & -0.17 & -0.87 & 0.77 & $-1.64 \pm 0.26$ & Basal & This paper \\
\hline 49 & $\begin{array}{l}\text { Sea } \\
\text { Breeze }\end{array}$ & 39.3229 & -75.3160 & $\begin{array}{l}\text { OS- } \\
80667\end{array}$ & $1010 \pm 25$ & $969-804$ & -0.16 & -1.37 & 0.77 & $-2.14 \pm 0.26$ & Basal & This paper \\
\hline 50 & $\begin{array}{l}\text { Sea } \\
\text { Breeze }\end{array}$ & 39.3191 & -75.3179 & $\begin{array}{l}\text { OS- } \\
80663\end{array}$ & $1010 \pm 25$ & $969-804$ & -0.06 & -1.71 & 0.23 & $-1.94 \pm 0.40$ & $\begin{array}{l}\text { Intercala } \\
\text { ted }\end{array}$ & $\begin{array}{l}\text { Nikitina et al. } \\
\text { (2014) }\end{array}$ \\
\hline 51 & $\begin{array}{l}\text { Sea } \\
\text { Breeze }\end{array}$ & 39.3191 & -75.3179 & $\begin{array}{l}\text { Beta- } \\
252035\end{array}$ & $1070 \pm 40$ & $1059-927$ & -0.06 & -1.89 & 0.23 & $-2.12 \pm 0.40$ & $\begin{array}{l}\text { Intercala } \\
\text { ted }\end{array}$ & $\begin{array}{l}\text { Nikitina et al. } \\
\text { (2014) }\end{array}$ \\
\hline 52 & $\begin{array}{l}\text { Sea } \\
\text { Breeze }\end{array}$ & 39.3162 & -75.3153 & $\begin{array}{l}\text { OS- } \\
84499\end{array}$ & $1090 \pm 25$ & $1057-938$ & -0.16 & -1.53 & 0.77 & $-2.30 \pm 0.26$ & $\begin{array}{l}\text { Intercala } \\
\text { ted }\end{array}$ & $\begin{array}{l}\text { Nikitina et al. } \\
\text { (2014) }\end{array}$ \\
\hline 53 & $\begin{array}{l}\text { Sea } \\
\text { Breeze }\end{array}$ & 39.3191 & -75.3179 & $\begin{array}{l}\text { OS- } \\
80664\end{array}$ & $1170 \pm 30$ & $1179-986$ & -0.07 & -1.95 & 0.23 & $-2.18 \pm 0.40$ & $\begin{array}{l}\text { Intercala } \\
\text { ted }\end{array}$ & $\begin{array}{l}\text { Nikitina et al. } \\
\text { (2014) }\end{array}$ \\
\hline 54 & $\begin{array}{l}\text { Sea } \\
\text { Breeze }\end{array}$ & 39.3220 & -75.3173 & $\begin{array}{l}\text { OS- } \\
88663\end{array}$ & $1260 \pm 25$ & $1280-1091$ & -0.16 & -1.61 & 0.77 & $-2.38 \pm 0.26$ & Basal & This paper \\
\hline 55 & $\begin{array}{l}\text { Sea } \\
\text { Breeze }\end{array}$ & 39.3191 & -75.3179 & $\begin{array}{l}\text { Beta- } \\
252036\end{array}$ & $1460 \pm 40$ & $1413-1292$ & -0.06 & -2.65 & 0.23 & $-2.88 \pm 0.40$ & $\begin{array}{l}\text { Intercala } \\
\text { ted }\end{array}$ & $\begin{array}{l}\text { Nikitina et al. } \\
\text { (2014) }\end{array}$ \\
\hline
\end{tabular}




\begin{tabular}{|c|c|c|c|c|c|c|c|c|c|c|c|c|}
\hline 56 & $\begin{array}{l}\text { Sea } \\
\text { Breeze }\end{array}$ & 39.3204 & -75.3177 & $\begin{array}{l}\text { OS- } \\
84496\end{array}$ & $1550 \pm 25$ & $1524-1385$ & -0.17 & -2.31 & 0.77 & $-3.08 \pm 0.26$ & $\begin{array}{l}\text { Intercala } \\
\text { ted }\end{array}$ & $\begin{array}{l}\text { Nikitina et al. } \\
\text { (2014) }\end{array}$ \\
\hline 57 & $\begin{array}{l}\text { Sea } \\
\text { Breeze }\end{array}$ & 39.3217 & -75.3181 & $\begin{array}{l}\text { OS- } \\
80666\end{array}$ & $1740 \pm 30$ & $1713-1566$ & -0.40 & -2.05 & 0.54 & $-2.59 \pm 0.23$ & Basal & This paper \\
\hline 58 & $\begin{array}{l}\text { Sea } \\
\text { Breeze }\end{array}$ & 39.3162 & -75.3153 & $\begin{array}{l}\text { OS- } \\
84497\end{array}$ & $1760 \pm 25$ & $1734-1571$ & -0.40 & -2.49 & 0.54 & $-3.03 \pm 0.24$ & Basal & This paper \\
\hline 59 & $\begin{array}{l}\text { Sea } \\
\text { Breeze }\end{array}$ & 39.3217 & -75.3193 & $\begin{array}{l}\text { OS- } \\
88661\end{array}$ & $1840 \pm 30$ & $1864-1708$ & -0.40 & -2.59 & 0.54 & $-3.13 \pm 0.23$ & Basal & This paper \\
\hline 60 & $\begin{array}{l}\text { Sea } \\
\text { Breeze }\end{array}$ & 39.3146 & -75.3158 & $\begin{array}{l}\text { OS- } \\
88743\end{array}$ & $2210 \pm 30$ & $2319-2148$ & -0.39 & -3.27 & 0.54 & $-3.81 \pm 0.24$ & $\begin{array}{l}\text { Base of } \\
\text { Basal }\end{array}$ & This paper \\
\hline 61 & $\begin{array}{l}\text { Sea } \\
\text { Breeze }\end{array}$ & 39.3146 & -75.3158 & $\begin{array}{l}\text { Beta- } \\
240761\end{array}$ & $2240 \pm 40$ & $2341-2153$ & -0.39 & -3.03 & 0.54 & $-3.57 \pm 0.24$ & Basal & $\begin{array}{l}\text { Nikitina et al. } \\
\text { (2014) }\end{array}$ \\
\hline 62 & $\begin{array}{l}\text { Slaughter } \\
\text { Beach }\end{array}$ & 38.9047 & -75.2964 & I-9230 & $720 \pm 80$ & $792-540$ & -0.05 & -0.97 & 0.40 & $-1.37 \pm 0.97$ & $\begin{array}{l}\text { Intercala } \\
\text { ted }\end{array}$ & Kraft (1976) \\
\hline 63 & $\begin{array}{l}\text { Slaughter } \\
\text { Beach }\end{array}$ & 38.9261 & -75.3222 & I-9228 & $1690 \pm 85$ & $1813-1409$ & -0.05 & -1.98 & 0.40 & $-2.38 \pm 0.97$ & $\begin{array}{l}\text { Intercala } \\
\text { ted }\end{array}$ & Kraft (1976) \\
\hline 64 & $\begin{array}{l}\text { Slaughter } \\
\text { Beach }\end{array}$ & 38.9317 & -75.3175 & TEM-172 & $2020 \pm 110$ & $2306-1721$ & -0.08 & -4.32 & 0.73 & $-5.05 \pm 0.82$ & Basal & Marx (1981) \\
\hline 65 & Smyrna & 39.3017 & -75.5983 & DC-3_c & $1370 \pm 110$ & $1524-1058$ & -0.10 & -2.32 & 0.38 & $-2.70 \pm 0.68$ & $\begin{array}{l}\text { Intercala } \\
\text { ted }\end{array}$ & $\begin{array}{l}\text { Rogers \& } \\
\text { Pizzuto } \\
(1994)\end{array}$ \\
\hline
\end{tabular}


TABLE 3: RATES OF RELATIVE SEA-LEVEL RISE (2200-150 YEARS BP) WITH AND WITHOUT PALEOTIDAL RANGE CORRECTION

\begin{tabular}{|c|c|c|c|c|c|c|}
\hline \multirow{3}{*}{$\begin{array}{l}\text { Location } \\
\text { Delaware Bay } \\
\text { Delaware Bay ex. Cape Henlopen, } \\
\text { Great Marsh and Jake Landing }\end{array}$} & \multicolumn{3}{|c|}{$\begin{array}{c}\begin{array}{c}\text { Rate with tidal } \\
\text { correction }(\mathrm{mm} / \mathrm{yr} \\
\pm 2 \sigma)\end{array} \\
\end{array}$} & \multicolumn{3}{|c|}{$\begin{array}{c}\text { Rate without tidal } \\
\text { correction }(\mathrm{mm} / \mathrm{yr} ; \\
\pm 2 \sigma)\end{array}$} \\
\hline & 1.19 & \pm & 0.26 & 1.25 & \pm & 0.26 \\
\hline & 1.25 & \pm & 0.27 & 1.33 & \pm & 0.28 \\
\hline Upper Bay & 1.26 & \pm & 0.33 & 1.45 & \pm & 0.34 \\
\hline Sea Breeze & 1.12 & \pm & 0.22 & 1.33 & \pm & 0.23 \\
\hline Smyrna & 1.15 & \pm & 0.63 & 1.33 & \pm & 0.65 \\
\hline Leipsic River & 1.27 & \pm & 0.30 & 1.48 & \pm & 0.31 \\
\hline Jakes Landing & 1.49 & \pm & 0.87 & 1.64 & \pm & 0.90 \\
\hline Lower Bay & 1.15 & \pm & 0.29 & 1.11 & \pm & 0.30 \\
\hline $\begin{array}{l}\text { Lower Bay ex. Cape Henlopen, } \\
\text { Great Marsh }\end{array}$ & 1.30 & \pm & 0.36 & 1.21 & \pm & 0.36 \\
\hline Bowers & 1.19 & \pm & 0.45 & 1.24 & \pm & 0.45 \\
\hline Slaughter Beach & 1.33 & \pm & 0.54 & 1.34 & \pm & 0.54 \\
\hline Great Marsh & 0.69 & \pm & 0.33 & 0.78 & \pm & 0.34 \\
\hline Cape Henlopen & 1.00 & \pm & 0.40 & 1.05 & \pm & 0.40 \\
\hline Horse Island Marsh & 1.39 & \pm & 0.48 & 1.14 & \pm & 0.49 \\
\hline Rehoboth Bay & 1.29 & \pm & 0.78 & 1.10 & \pm & 0.78 \\
\hline
\end{tabular}




\section{FIGURE CAPTIONS}

Figure 1: (A) Map of the Delaware Bay and coast of southern New Jersey, USA showing the location of sites referred to in the main text. (B) Location of the Sea Breeze, NJ study site on the north coast of the Delaware Bay. The location of cores used to reconstruct relative sea level are shown and the transects used to describe sediment beneath the Sea Breeze salt marsh.

Figure 2: Stratigraphy underlying Sea Breeze described from a series of cores collected along transects. These transects are a subset of (and modified from) those used by Nikitina et al. (2014). The basal sand-peat contact was targeted to produce compaction-free relative sea-level reconstructions across a range of elevations. Ages shown for radiocarbon dates are in radiocarbon years.

Figure 3: Microfossil diagram for sea-level index point from cores (A) SB30, (B) SB32, (C) SB76, (D) SB81, (E) SB83, (F) SB84, (G) SB98, (H) SB110. Foraminifera expressed as \% as relative abundances. Red bars indicate assemblage (expressed as percentage) at radiocarbon-dated level, grey bars represent other counts. Samples were few individuals of the indicated species were present are represented by ' + ' symbols. Depth (m) down-core shown to the left of the lithology column. Core-top altitudes (m MTL) are listed above each lithology column.

Figure 4: Contours of Great Diurnal Range (GT) calculated from the tidal model of Hall et al. (2013) for Delaware Bay and the Western North Atlantic illustrating temporal changes at (A) present day, (B) 1000 years BP, (C) 2000 years BP, and (D) 3000 years BP.

Figure 5: Relative sea level (RSL) reconstructions. Sea level index points are represented by boxes with a width that includes $2 \sigma$ calibrated radiocarbon ages and height includes sea level uncertainty. (A) RSL reconstructions from Sea Breeze before and after correction for tidal-range change. (B) Basal sea level index points from Delaware (Engelhart and Horton, 2012), and Sea Breeze (this study) corrected for tidal range. (C) Basal sea level index points from New Jersey (Engelhart and Horton, 2012), and Sea Breeze (this study) corrected for tidal range.

Figure 6: Average relative sea-level rise field (2200-150 BP) estimated for the entire study area (A) without and (C) with paleotidal range correction. Uncolored areas exhibit a posterior variance $>10 \%$ of the prior variance. (B, D) This field is sub-sampled to obtain rates for individual sites. (1) Sea Breeze; (2) Smyrna; (3) Leipsic River; (4) Bowers; (5) Slaughter Beach; (6) Great Marsh/Broadkill Beach; (7) Cape Henlopen; (8) Horse Island Marsh/Marsh Island; (9) Rehoboth Bay; (10) Jake_s Landing. 


\section{REFERENCES}

Bassett, S.E., Milne, G.A., Mitrovica, J.X., Clark, P.U., 2005. Ice sheet and solid earth influences on far-field sea-level histories. Science 309, 925-928.

Belknap, D.F., 1975, Dating of Late Pleistocene and Holocene relative sea levels in coastal Delaware. Unpub. M.S. thesis, Department of Geology, University of Delaware, Newark, 95 pp.

Belknap, D.F., Kraft, J.C., 1977. Holocene relative sea-level changes an coastal stratigraphic units on the Northwest flank of the Baltimore Canyon trough geocincline. Journal of Sedimentary Petrology 47, 610-629.

Bloom, A.L., 1964. Peat accumulation and compaction in Connecticut coastal marsh. Journal of Sedimentary Research 34, 599-603. Brain, M.J., Long, A.J., Woodroffe, S.A., Petley, D.N., Milledge, D.G., Parnell, A.C., 2012. Modelling the effects of sediment compaction on salt marsh reconstructions of recent sea-level rise. Earth and Planetary Science Letters 345-348, 180-193.

Carlson, A.E., LeGrande, A.N., Oppo, D.W., Came, R.E., Schmidt, G.A., Anslow, F.S., Licciardi, J.M., Obbink, E.A., 2008. Rapid early Holocene deglaciation of the Laurentide ice sheet. Nature Geosci 1, 620-624.

Chmura, G.L., Aharon, P., 1995. Stable carbon isotope signatures of sedimentary carbon in coastal wetlands as indicators of salinity regime. Journal of Coastal Research 11, 124-135.

Church, J.A., White, N.J., 2011. Sea-level rise from the late 19th to the early 21st century. Surveys in Geophysics 32 , 585-602. Cook, G.T., van der Plicht, J., 2007. Radiocarbon dating: conventional method, in: Elias, R.W. (Ed.), Encyclopedia of Quaternary Science. Elsevier, Amsterdam, pp. 2899-2911.

Cressie, N., Wikle, C.K., 2011. Statistics for spatio-temporal data. Wiley, Hoboken, NJ.

Davis, J.L., Mitrovica, J.X., 1996. Glacial isostatic adjustment and the anomalous tide gauge record of eastern North America. Nature 379, 331-333.

Dickens, A.F., Gélinas, Y., Masiello, C.A., Wakeham, S., Hedges, J.I. 2004. Reburial of fossil organic carbon in marine sediments. Nature 427, 336-339.

Dutton, A., Carlson, A.E., Long, A.J., Milne, G.A., Clark, P.U., DeConto, R., Horton, B.P., Rahmstorf, S., Raymo, M.E. 2015. Sealevel rise due to polar ice-sheet mass loss during past warm periods. Science 349,doi:10.1126/science.aaa4019.

Egbert, G.D., Bennett, A.F., Foreman, M.G.G., 1994. TOPEX/POSEIDON tides estimated using a global inverse model. Journal of Geophysical Research: Oceans 99, 24821-24852.

Engelhart, S.E., Horton, B.P., 2012. Holocene sea level database for the Atlantic coast of the United States. Quaternary Science Reviews 54, 12-25.

Engelhart, S.E., Horton, B.P., Douglas, B.C., Peltier, W.R., Tornqvist, T.E., 2009. Spatial variability of late Holocene and 20th century sea-level rise along the Atlantic coast of the United States. Geology 37, 1115-1118.

Engelhart, S.E., Horton, B.P., Kemp, A.C., 2011a. Holocene sea level changes along the United States' Atlantic Coast. Oceanography 24, 70-79. 
Engelhart, S.E., Peltier, W.R., Horton, B.P., 2011b. Holocene relative sea-level changes and glacial isostatic adjustment of the U.S. Atlantic coast. Geology 39, 751-754.

Engelhart, S.E., Vacchi, M., Horton, B.P., Nelson, A.R., Kopp, R.E., 2015. Sea-level history of the Pacific coast of North America since the Last Glacial Maximum. Quaternary Science Reviews 113, 78-92.

Farrell, W.E., Clark, J.A., 1976. On postglacial sea level. Geophysical Journal of the Royal Astronomical Society $46,647-667$. Fletcher, C. H., Vanpelt, J. E., Brush, G. S., and Sherman, J., 1993. Tidal wetland record of Holocene sea-level movements and climate history. Palaeogeography Palaeoclimatology Palaeoecology 102, 177-213.

Gehrels, W.R., 1994. Determining relative sea-level change from salt-marsh foraminifera and plant zones on the coast of Maine, U.S.A. Journal of Coastal Research 10, 990-1009.

Gehrels, W.R., Woodworth, P.L., 2012. When did modern rates of sea-level rise start? Global and Planetary Change 100, $263-277$. Grimm, E.C., Maher Jr, L.J., Nelson, D.M., 2009. The magnitude of error in conventional bulk-sediment radiocarbon dates from central North America. Quaternary Research 72, 301-308.

Hall, G.F., Hill, D.F., Horton, B.P., Engelhart, S.E., Peltier, W.R., 2013. A high-resolution study of tides in the Delaware Bay: Past conditions and future scenarios. Geophysical Research Letters 40, 338-342.

Hijma, M.P., Engelhart, S.E., Tornqvist, T.E., Horton, B.P., Hu, P. and Hill, D.E., 2015. A protocol for a geological sea-level database. In: Shennan, I., Long, A.J., Horton, B.P. (Eds.), Handbook fof Sea-Level Research. Wiley-Blackwell, pp. 295-311 . Hill, D.F., Griffiths, S.D., Peltier, W.R., Horton, B.P., Tornqvist, T.E., 2011. High-resolution numerical modeling of tides in the western Atlantic, Gulf of Mexico, and Caribbean Sea during the Holocene. Journal of Geophysical Research 116. Horton, B.P. Edwards, R.J., Lloyd, J.M., 2000. Implications of a microfossil transfer function in Holocene sea-level studies. Geological Society Special Publication 166, 41-54.

Horton, B., Engelhart, S.E., Hill, D.F., Kemp, A.C., Nikitina, D.L., Miller, K.G., Peltier, R.W., 2013. Influence of tidal-range change and sediment compaction on Holocene relative sea-level change in New Jersey, USA. Journal of Quaternary Science $28,403-411$.

Horton, B.P., Edwards, R.J., 2006. Quantifying Holocene sea-level change using intertidal foraminifera: lessons from the British Isles. Cushman Foundation for Foraminiferal Research, Special Publication 40, 97.

Horton, B.P., Shennan, I., 2009. Compaction of Holocene strata and the implications for relative sealevel change on the east coast of England. Geology 37, 1083-1086.

$\mathrm{Hu}, \mathrm{P}$. 2010. Developing a quality-controlled postglacialsea-level database for coastal Louisiana to assess conflicting hypotheses of Gulf Coast sea-level change. Unpub. M.S. thesis, Tulane University.

Kaye, C.A., Barghoorn, E.S., 1964. Late Quaternary sea-level change and crustal rise at Boston, Massachusetts, with notes on the autocompaction of peat. Geological Society of America Bulletin 75, 63-80.

Kemp, A.C., Bernhardt, C.E., Horton, B.P., Kopp, R.E., Vane, C.H., Peltier, W.R., Hawkes, A.D., Donnelly, J.P., Parnell, A.C., Cahill, N., 2014. Late Holocene sea- and land-level change on the U.S. southeastern Atlantic coast. Marine Geology 357: 90-100. 
Kemp, A.C., Horton, B.P., Vane, C.H., Corbett, D.R., Bernhardt, C.E., Engelhart, S.E., Anisfeld, S.C., Parnell, A.C., Cahill, N., 2013a. Sea-level change during the last 2500 years in New Jersey, USA. Quaternary Science Reviews 81, 90-104.

Kemp, A.C., Nelson, A.R., Horton, B.P., 2013b. Radiocarbon dating of plant macrofossils in tidal marsh sediment, in: Schroder, J. (Ed.), Treatise on Geomorphology. Academic Press, San Diego, CA, pp. 370-388.

Kemp, A.C., Telford, R.J., Horton, B.P., Anisfeld, S.C., Sommerfield, C.K., 2013c. Reconstructing Holocene sea-level using saltmarsh foraminifera and transfer functions: lessons from New Jersey, USA. Journal of Quaternary Science 28, 617-629.

Kemp, A.C., Horton, B.P., Vann, D.R., Engelhart, S.E., Vane, C.H., Nikitina, D., Anisfeld, S.C., 2012a. Quantitative vertical zonation of salt-marsh foraminifera for reconstructing former sea level; an example from New Jersey, USA. Quaternary Science Reviews 54, 26-39.

Kemp, A.C., Vane, C.H., Horton, B.P., Engelhart, S.E., Nikitina, D., 2012b. Application of stable carbon isotopes for reconstructing salt-marsh floral zones and relative sea level, New Jersey, USA. Journal of Quaternary Science 27, 404-414.

Kopp, R.E., 2013. Does the mid-Atlantic United States sea level acceleration hot spot reflect ocean dynamic variability? Geophysical Research Letters 40, 3981-3985.

Kopp, R. E., Horton, R.M., Little, C.M., Mitrovica, J.X., Oppenheimer, M., Rasmussen, D.J., Strauss, B.H., Tebaldi, C., 2014. Probabilistic 21st and 22nd century sea-level projections at a global network of tide gauge sites. Earth's Future 2: 287-306. Kopp, R.E., Hay, C.C., Little, C.M., Mitrovica, J.X., 2015. Geographic variability of sea-level change. Current Climate Change Reports. doi: 10.1007/s40641-015-0015-5.

Kopp, R.E., Horton, B.P., Kemp, A.C., Tebaldi, C., In Press. Past and future sea-level rise along the coast of North Carolina, USA. Climatic Change.

Kraft, J.C., 1976. Radiocarbon dates in the Delaware coastal zone. University of Delaware Sea Grant Publication 19-76, 20pp.

Kraft, J.C., John, C.J., Maurmeyer, E.M., 1978. Morphology of coastal barriers, Delaware, U.S.A. Coastal Engineering Proceedings. Lambeck, K., 2002. Sea level change from mid-Holocene to recent time: an Australian example with global implications, in:

Mitrovica, J.X., Vermeersen, B. (Eds.), Glacial Isostatic Adjustment and the Earth System. American Geophysical Union, pp. 33-50. Lambeck, K., Rouby, H., Purcell, A., Sun, Y., Sambridge, M., 2014. Sea level and global ice volumes from the Last Glacial Maximum to the Holocene. Proceedings of the National Academy of Sciences 111, 15296-15303.

Leorri, E., Martin, R., McLaughlin, P., 2006. Holocene environmental and parasequence development of the St. Jones Estuary, Delaware (USA): Foraminiferal proxies of natural climatic and anthropogenic change. Palaeogeography, Palaeoclimatology, Palaeoecology 241, 590-607.

Leorri, E., Mulligan, R., Mallinson, D., Cearreta, A., 2011. Sea-level rise and local tidal range changes in coastal embayments: An added complexity in developing reliable sea-level index points. Journal of Integrated Coastal Zone Management 11, $307-314$. Long, A.J., Barlow, N.L.M., Gehrels, W.R., Saher, M.H., Woodworth, P.L., Scaife, R.G., Brain, M.J., Cahill, N., 2014. Contrasting records of sea-level change in the eastern and western North Atlantic during the last 300 years. Earth and Planetary Science Letters $388,110-122$ 
Luettich, R.A., Westerink, J.J., 1991. A solution for the vertical variation of stress, rather than velocity, in a three-dimensional circulation model. International Journal for Numerical Methods in Fluids 12, 911-928.

Marx, P.R., 1981., A dynamic model for an estuarine transgression based on facies variants in the nearshore of western Delaware Bay. Unpub. M.S. thesis, Department of Geology, University of Delaware, Newark, 183pp.

McHutchon, A., Rasmussen, C.E., 2011. Gaussian process training with input noise, Advances in Neural Information Processing Systems, pp. 1341-1349.

Meyerson, A.L., 1972. Pollen and paleosalinity analyses from a Holocene tidal marsh sequence, Cape May County, New Jersey. Marine Geology 12, 335-357.

Miller, K.G., Kopp, R.E., Horton, B.P., Browning, J.V., Kemp, A.C., 2013. A geological perspective on sea-level rise and its impacts along the U.S. mid-Atlantic coast. Earth's Future.

Milne, G.A., Long, A.J., Bassett, S.E., 2005. Modelling Holocene relative sea-level observations from the Caribbean and South America. Quaternary Science Reviews 24, 1183-1202.

Mofjeld, H.O., Venturato, A.J., González, F.I., Titov, V.V., Newman, J.C., 2004. The harmonic constant datum method: options for overcoming datum discontinuities at mixed-diurnal tidal transitions. Journal of Atmospheric and Oceanic Technology 21, 95-104.

Mukai, A.Y., Westerink, J.J., Luettich, R.A., Mark, D., 2002. Eastcoast 2001, A Tidal Constituent Database for Western North Atlantic, Gulf of Mexico, and Caribbean Sea. Engineer research and development center Vicksburg, MS coastal and hydraulics lab, p. 196.

Nerem, R.S., Chambers, D.P., Choe, C., Mitchum, G.T., 2010. Estimating Mean Sea Level Change from the TOPEX and Jason Altimeter Missions. Marine Geodesy 33, 435-446.

Niering, W.A., Warren, R.S., Weymouth, C.G., 1977. Our dynamic tidal marshes: vegetation changes as revealed by peat analysis, The Connecticut Arboretum Bulletin, 22 ed, p. 12.

Nikitina, D.L., Pizzuto, J. E., Schwimmer, R. A., Ramsey, K. W., 2000. An updated Holocene sea-level curve for the Delaware coast. Marine Geology 124, 137-159.

Nikitina, D., Pizzuto, J.E., Martin, R.E., Hippensteel, S.P., 2003. Transgressive valley-fill stratigraphy and sea-level history of the Leipsic River, Bombay Hook National Wildlife refuge, Delaware, USA, in: Olson, H.C., Leckie, R.M. (Eds.), Micorpaleontologic proxies for sea-level change and stratigraphic discontinuities, pp. 51-62.

Nikitina, D.L., Kemp, A.C., Horton, B.P., Vane, C.H., van de Plassche, O., Engelhart, S.E., 2014. Storm erosion during the past 2000 years along the north shore of Delaware Bay, USA. Geomorphology 208, 160-172.

Peltier, W.R., 1996. Global sea level rise and glacial isostatic adjustment: an analysis of data from the east coast of North America. Geophysical Research Letters 23, GL00848.

Peltier, W.R., 1998. Postglacial variations in the level of the sea: Implications for climate dynamics and solid-Earth geophysics. Reviews of Geophysics 36, 603-689.

Peltier, W.R., 2002. On eustatic sea level history: Last Glacial Maximum to Holocene. Quaternary Science Reviews 21, $377-396$. 
Rasmussen, C.E., Williams, C.I.K., 2005. Gaussian Processes for Machine Learning. Massachusetts Institue of Technology Press. Redfield, A.C., 1972. Development of a New England salt marsh. Ecological Monographs 42, 201-237.

Reimer, P.J., Bard, E., Bayliss, A., Beck, J.W., Blackwell, P.G., Bronk Ramsey, C., Grootes, P.M., Guilderson, T.P., Haflidason, H., Hajdas, I., Hatté, C., Heaton, T.J., Hoffmann, D.L., Hogg, A.G., Hughen, K.A., Kaiser, K.F., Kromer, B., Manning, S.W., Niu, M., Reimer, R.W., Richards, D.A., Scott, E.M., Southon, J.R., Staff, R.A., Turney, C.S.M., van der Plicht, J., 2013. IntCal13 and Marine13 Radiocarbon Age Calibration Curves 0-50,000 Years cal BP. Radiocarbon 55.

Rogers, E.E., Pizzuto, J.E., 1994. The Holocene stratigraphy of three freshwater to brackish wetlands, Kent County, Delaware, in: Kellogg, D.C., Cluster, J.F. (Eds.), Paleoenvironmental studies of the State Route 1 Corridor: contexts for prehistoric settlement, New Castle and Kent counties, Delaware. Delaware Department of Transportation Archeology Series 114, 48-81.

Rowley, D.B., Forte, A.M., Moucha, R., Mitrovica, J.X., Simmons, N.A., Grand, S.P., 2013. Dynamic Topography Change of the Eastern United States Since 3 Million Years Ago. Science 340, 1560-1563.

Roy, K., Peltier, W.R., 2015. Glacial isostatic adjustment, relative sea level history and mantle viscosity: Reconciling relative sea level model predictions for the U.S. East coast with geological constraints. Geophysical Journal International 201, 1156-1181.

Sella, G.F., Stein, S., Dixon, T.H., Craymer, M., James, T.S., Mazzotti, S., Dokka, R.K., 2007. Observation of glacial isostatic adjustment in "stable" North America with GPS. Geophysical Research Letters 34, L02306.

Shennan, I., 1986. Flandrian sea-level changes in the Fenland, II: Tendencies of sea-level movement, altitudinal changes and local and regional factors. Journal of Quaternary Science 1, 155-179.

Shennan, I., Horton, B., 2002. Holocene land-and sea-level changes in Great Britain. Journal of Quaternary Science 17, $511-526$. Shennan, I., Lambeck, K., Flather, R., Horton, B., McArthur, J., Innes, J., Lloyd, J., Rutherford, M., Wingfield, R., 2000. Modelling western North Sea palaeogeographies and tidal changes during the Holocene, in: Shennan, I., Andrews, J. (Eds.), Holocene LandOcean Interaction and Environmental Change around the North Sea. Geological Society Special Publications, London, pp. pp. 299319.

Snay, R., Cline, M., Dillinger, W., Foote, R., Hilla, S., Kass, W., Ray, J., Rohde, J., Sella, G., Soler, T., 2007. Using global positioning system-derived crustal velocities to estimate rates of absolute sea level change from North American tide gauge records. Journal of Geophysical Research 112, B04409.

Stedman, S.M., 1990. Sedimentology and Stratigraphy of the Grat Marsh, Lewes, Delaware. Unpub. M.S. thesis, University of Delaware, Newark, 143pp.

Törnqvist, T.E., De Jong, A.F.M., Van der Borg, K., 1990. Comparison of AMS ${ }^{14}$ C ages of organic deposits and macrofossils: a progress report. Nuclear Instruments and Methods in Physics Research B 52, 442-445.

van de Plassche, O., 1982. Sea-level change and water-level movements in the Netherlands during the Holocene. Mededelingen rijks geologische dienst 36, 1.

Törnqvist, T.E., Rosenheim, B., Hu, P., Fernandez, A.B., 2015. Radiocarbon dating and calibration. In: Shennan, I., Long, A.J., Horton, B.P. (Eds.) The Handbook of Sea-Level Research. Wiley-Blackwell, pp. 349-360. 
van de Plassche, O., 1986. Sea-level research: a manual for the collection and evaluation of data. Geebooks, Norwich.

van de Plassche, O., 1991. Late Holocene sea-level fluctuations on the shore of Connecticut inferred from transgressive and regressive overlap boundaries in salt-marsh deposits. Journal of Coastal Research 11, 159-179.

van de Plassche, O., Wright, A.J., Horton, B.P., Engelhart, S.E., Kemp, A.C., Mallinson, D., Kopp, R.E., 2014. Estimating tectonic uplift of the Cape Fear Arch (south-eastern United States) using reconstructions of Holocene relative sea level. Journal of Quaternary Science 29, 749-759.

Varekamp, J.C., Thomas, E., 1998. Climate Change and the Rise and Fall of Sea Level Over the Millennium. EOS 79, pp. 69, 74-75. Wikle, C.K., Milliff, R.F., Nychka, D., Berliner, L.M., 2001. Spatiotemporal hierarchical Bayesian modeling: Tropical ocean surface winds. Journal of the American Statistical Association 96, 382-397.

Woodroffe, S., Barlow, N.L.M., 2015. Reference water level and tidal datum, in: Shennan, I., Long, A.J., Horton, B.P. (Eds.), Handbook fof Sea-Level Research. Wiley-Blackwell, pp. 171-182 .

Wu, J., Levin, S.A., 1997. A patch-based spatial modeling approach: conceptual framework and simulation scheme. Ecol. Model. 101, $325-346$. 


\section{Figures}

\section{Figure 1}

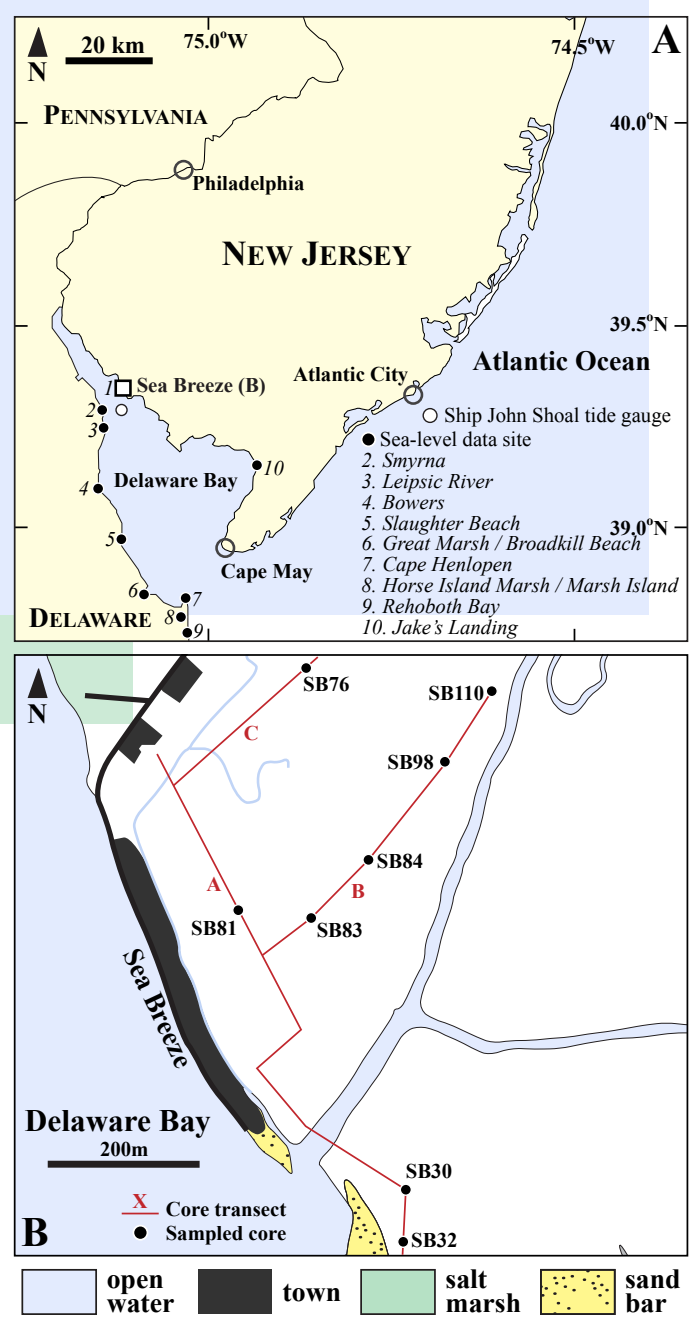




\section{Figure 2}
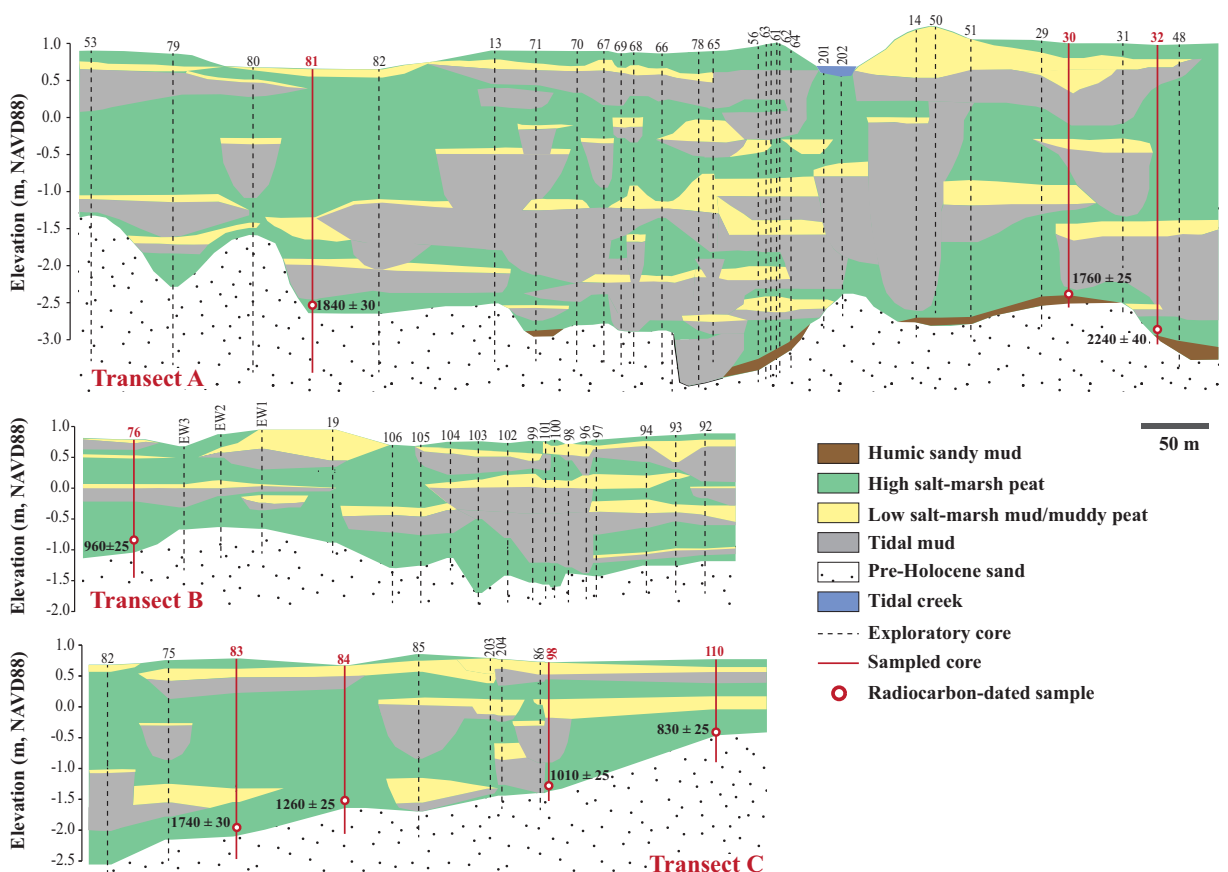

Humic sandy mud

$50 \mathrm{~m}$

High salt-marsh peat

Low salt-marsh mud/muddy peat

Tidal mud

Pre-Holocene sand

Tidal creek

Exploratory core

Sampled core

- Radiocarbon-dated sample 


\section{Figure 3}
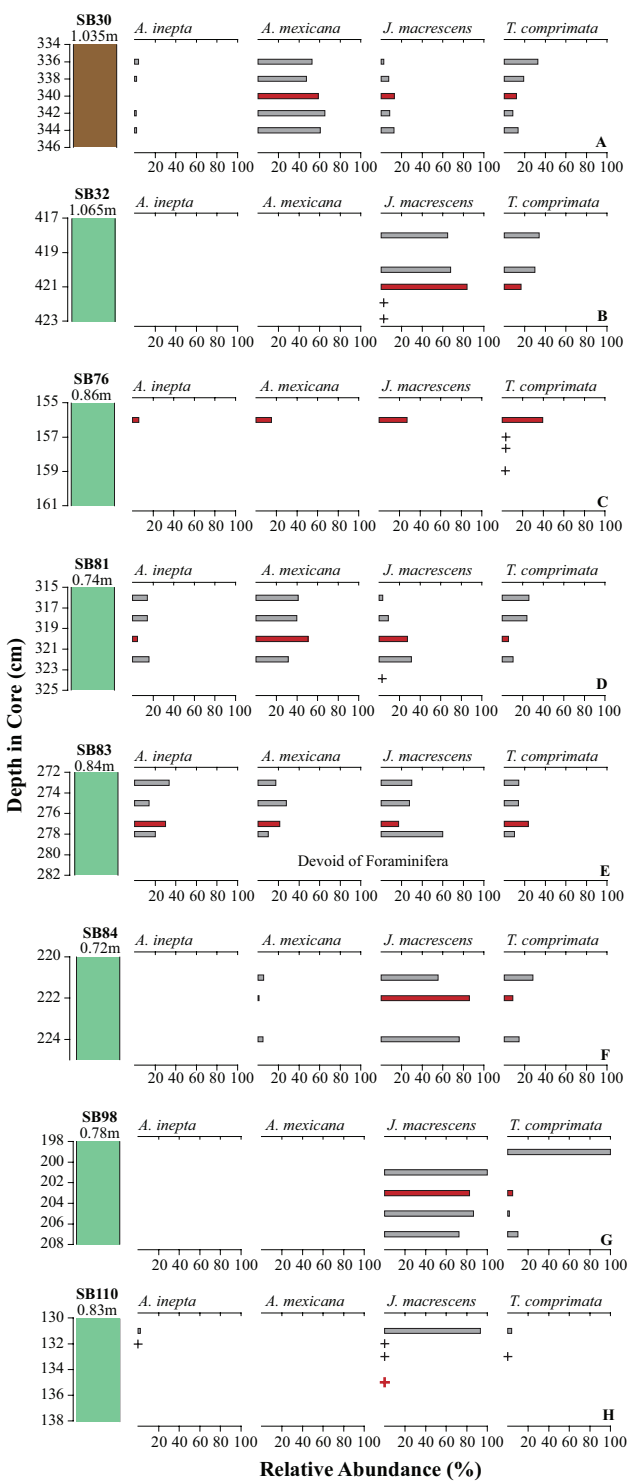

Humic sandy mud $\quad$ Radiocarbon dated depth

High salt-marsh peat + Species present, but few total individuals 
Figure 4

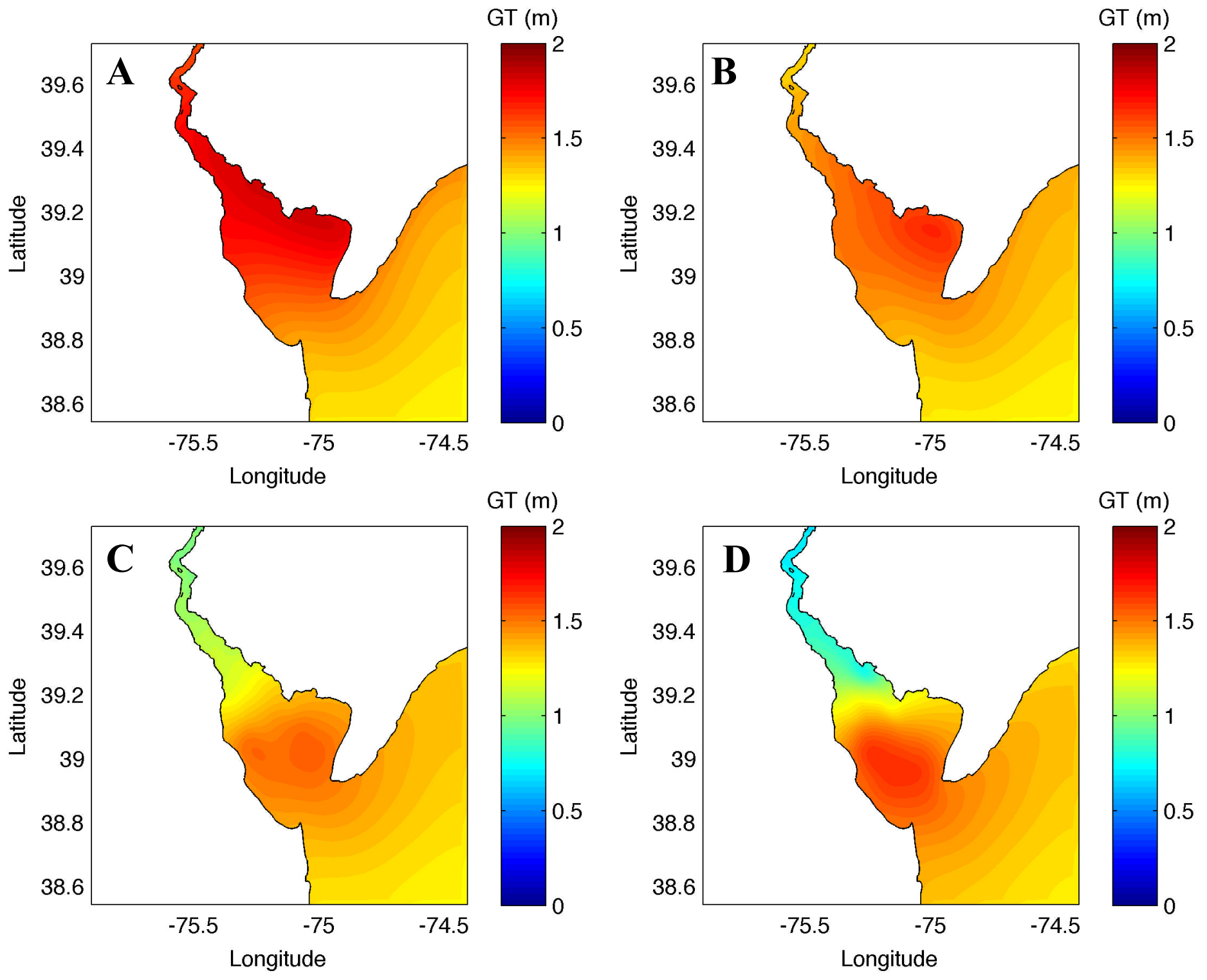




\section{Figure 5}

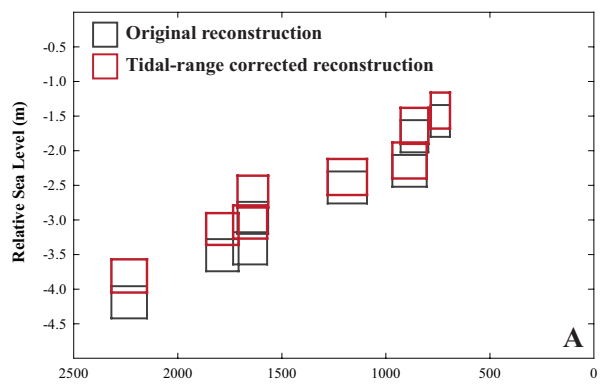

$\square$ Basal $\square$ Intercalated $\square$ Sea Breeze (tidal-range corrected)
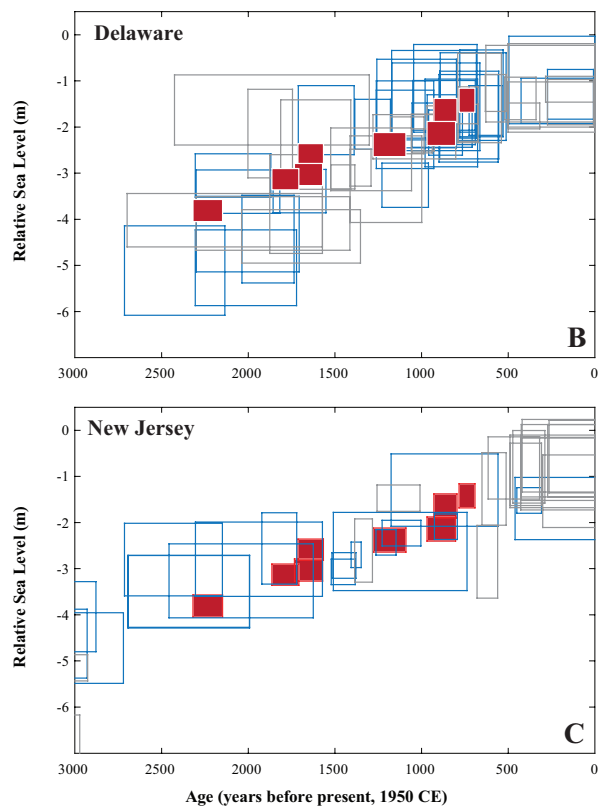
Figure 6

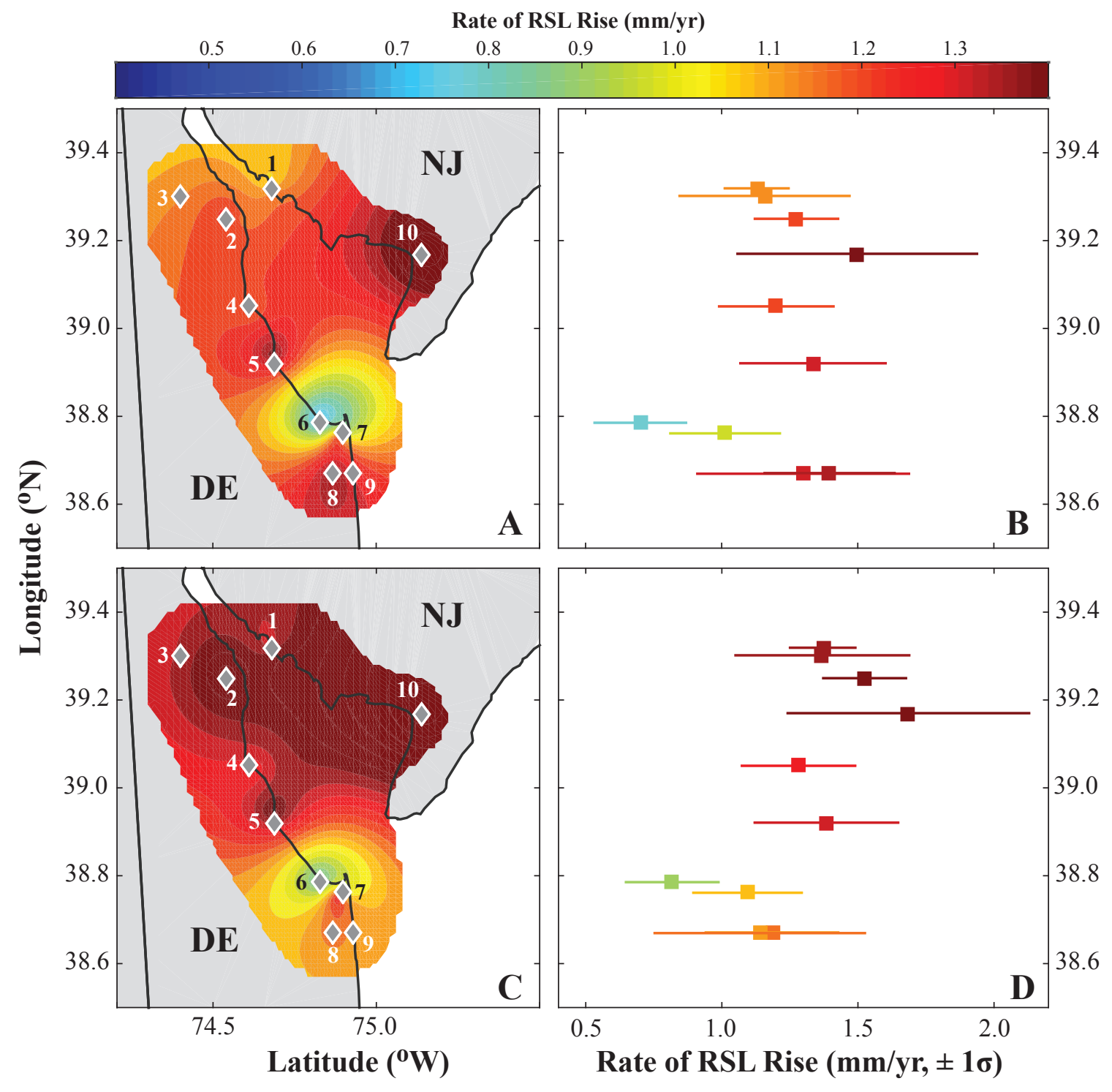

